\title{
Effects of a Flavonoid-Rich Fraction on the Acquisition and Extinction of Fear Memory: Pharmacological and Molecular Approaches
}

\author{
Daniela R. de Oliveira ${ }^{1,2}$, Claudia R. Zamberlam ${ }^{1,2}$, Gizelda M. Rêgo ${ }^{3}$, Alberto Cavalheiro ${ }^{4}$ \\ Janete M. Cerutti ${ }^{2}$ and Suzete M. Cerutti ${ }^{1 *}$ \\ ${ }^{1}$ Cellular and Behavioral Pharmacology Laboratory, Department of Biological Science, Universidade Federal de São Paulo, \\ São Paulo, Brazil, ${ }^{2}$ Genetic Bases of Thyroid Tumor Laboratory, Division of Genetics, Department of Morphology and \\ Genetics, Universidade Federal de São Paulo, São Paulo, Brazil, ${ }^{3}$ Department of Forestry Colombo, Brazilian Agricultural \\ Research Corporation, Colombo, Brazil, ${ }^{4}$ Institute of Chemistry, Nuclei of Bioassay, Biosynthesis and Ecophysiology of \\ Natural Products, São Paulo State University, Universidade Estadual Paulista, Araraquara, Brazil
}

OPEN ACCESS

Edited by: Onur Gunturkun, Ruhr-Universität Bochum, Germany

Reviewed by: Carsten T. Wotjak, Max-Planck-Institute of Psychiatry, Germany

Hongjoo J. Lee, University of Texas, USA

*Correspondence:

Suzete M. Cerutti smcerutti@unifesp.br

Received: 19 June 2015 Accepted: 23 November 2015 Published: 05 January 2016

Citation: de Oliveira DR, Zamberlam $C R$, Rêgo GM, Cavalheiro A, Cerutti JM and Cerutti SM (2016) Effects of a

Flavonoid-Rich Fraction on the Acquisition and Extinction of Fear

Memory: Pharmacological and Molecular Approaches.

Front. Behav. Neurosci. 9:345.

doi: 10.3389/fnbeh.2015.00345
The effects of flavonoids have been correlated with their ability to modulate the glutamatergic, serotoninergic, and GABAergic neurotransmission; the major targets of these substances are N-methyl-D-aspartic acid receptor (NMDARs), serotonin type1A receptor (5- $\left.\mathrm{HT}_{1 \mathrm{~A}} \mathrm{Rs}\right)$, and the gamma-aminobutyric acid type A receptors (GABA $\mathrm{Rs}$ ). Several studies showed that these receptors are involved in the acquisition and extinction of fear memory. This study assessed the effects of treatment prior to conditioning with a flavonoid-rich fraction from the stem bark of Erythrina falcata (FfB) on the acquisition and extinction of the conditioned suppression following pharmacological manipulations and on gene expression in the dorsal hippocampus (DH). Adult male Wistar rats were treated before conditioned fear with $\mathrm{FfB}$, vehicle, an agonist or antagonist of the $5-\mathrm{HT}_{1 \mathrm{~A}} \mathrm{R}$, GABA $_{A}$ Rs or the GluN2B-NMDAR or one of these antagonists before FfB treatment. The effects of these treatments on fear memory retrieval, extinction training and extinction retrieval were evaluated at 48, 72 , and $98 \mathrm{~h}$ after conditioning, respectively. We found that activation of $\mathrm{GABA}_{A}$ Rs and inactivation of GluN2B-NMDARs play important roles in the acquisition of lick response suppression. FfB reversed the effect of blocking GluN2B-NMDARs on the conditioned fear and induced the spontaneous recovery. Blocking the 5-HT $1 \mathrm{~A}$ R and the GluN2B-NMDAR before FfB treatment seemed to be associated with weakening of the spontaneous recovery. Expression of analysis of DH samples via qPCR showed that FfB treatment resulted in the overexpression of Htr1a, Grin2a, Gabra5, and Erk2 after the retention test and of Htr1a and Erk2 after the extinction retention test. Moreover, blocking the 5-HT1ARs and the GluN2B-NMDARs before FfB treatment resulted in reduced Htr1a and Grin2b expression after the retention test, but played a distinct role in Grin2a and Erk2 expression, according session evaluated. We show for the first time that the serotoninergic and glutamatergic receptors are important targets for the effect of FfB on the conditioned fear and spontaneous recovery, in which the ERK signaling pathway appears to be modulated. Further, these results provide important information regarding the role of the $\mathrm{DH}$ in conditioned suppression. Taken together, our data suggest that FfB represents a potential therapy for preventing or treating memory impairments.

Keywords: flavones, fear memory, GABA $A$ R, 5- $\mathrm{HT}_{1 \mathrm{~A}} \mathrm{R}$, GluN2B-NMDAR 


\section{INTRODUCTION}

Several studies have investigated the effects of the extracts of flavonoid-rich plants or flavonoid molecules as potent modulators of brain structure and function, including their neuroprotective and chemopreventive properties and their beneficial effects on memory and cognition. The effects of flavonoids have been correlated with their ability to modulate the phosphorylation state of intracellular proteins via the activation or inhibition of protein kinases and phosphatases (GametPayrastre et al., 1999; Wang et al., 1999; Schroeter et al., 2002; Li et al., 2003; Hoffman et al., 2004; Joseph et al., 2005; Maher et al., 2006; Nakajima et al., 2007; Spencer, 2007; Vauzour et al., 2008; Williams et al., 2008; Lovera et al., 2012; Mansuri et al., 2014), to increase the level of 5-HT and its metabolites (Zhang et al., 2012) or to alter expression of $\mathrm{GABA}_{\mathrm{A}}$ receptors $\left(\mathrm{GABA}_{\mathrm{A}} \mathrm{Rs}\right)$ and/or glutamatergic N-methylD-aspartic acid (NMDA) receptors (NMDARs) (Wang et al., 2005, 2008; Rendeiro et al., 2014). In addition, studies addressing the effects of specific flavonoid subgroups, including flavanols, anthocyanins, flavanones, and flavones, have shown that these constituents display potential to act as cognition-enhancing and neuroprotective agents (Vauzour et al., 2008; Kehr et al., 2012; Rendeiro et al., 2013, 2014; Vauzour, 2014), to prevent many forms of cerebrovascular disease, or to function as anti-anxiety drugs (Hasenöhrl et al., 1998; Spencer, 2008; Zhang et al., 2012). Although studies ex vivo, in vivo, and in vitro have provided evidence supporting the effects of flavonoids on the central nervous system, the cellular, and molecular pathways through which these compounds modulate memory formation are not completely elucidated (Youdim et al., 2004; Nakajima et al., 2007; Spencer, 2007; Williams et al., 2008; Ballesteros et al., 2014; Kimura et al., 2014; Rendeiro et al., 2014). However, several studies have established that the hippocampus, which plays a central role as a substrate of fear memory and anxiety (Fendt and Fanselow, 1999; Sanders et al., 2003) and which is a component of the Behavioral Inhibition System (McNaughton and Gray, 2000), appears to be a target for the mnemonic effects of flavonoid metabolites (Bannerman et al., 2004; Wang et al., 2006, 2009; Williams et al., 2008; Rendeiro et al., 2012, 2014; Oliveira et al., 2013; Vauzour, 2014).

Previous studies from our laboratory have demonstrated the role of flavonoid-rich plant extracts, such as a standardized extract of Ginkgo biloba L. (EGb), in the modulation of fear memory (Oliveira et al., 2009, 2013) by inducing differential CREB-1, GAP-43, and GFAP gene and protein expression in the dorsal hippocampus (DH), the prefrontal cortex and the amygdaloid complex. Further, we have established that crude extracts, fractions, and flavonoid molecules isolated from the stem bark of Erythrina falcata (CE) improved the acquisition of conditioned fear as evaluated by single-trial, step-down inhibitory avoidance (IA) (de Oliveira et al., 2014). Additionally, we used an IA procedure to show for the first time that treatment with flavones produces another well-established conditioning phenomenon, spontaneous recovery (de Oliveira et al., 2014). These findings corroborate with the results described in the literature and expand the understanding that flavonoids act as cognition-enhancing agents. However, these results raise new questions, which are highlighted below.

The first question concerns the anti-anxiety properties and cognitive effects of the flavonoid-rich fraction from $\mathrm{CE}$, given the various actions of flavonoids on the central nervous system. Despite the close relationship between fear memory and anxiety, these functions are dissociable at the behavioral, pharmacological, molecular, and neuroanatomical levels (McNaughton and Corr, 2004; Kalueff, 2007; Nakajima et al., 2007). The conditioned emotional response (CER) is a suitable animal model for studying the behavioral, pharmacological, and molecular mechanisms underlying fear memory and anxiety. To assess these phenomena, our lab has used the conditioned suppression of the lick response, in which the conditional stimulus (CS, tone), when associated with a noxious unconditioned stimulus (US, footshock), ultimately suppresses the licking response reinforced by water; i.e., the CS leads to the suppression of the ongoing behavior (Blanchard and Blanchard, 1969; Bolles and Collier, 1976; Fanselow, 1980; Sotty et al., 1996; Sanders et al., 2003). Fear responses (flight/fight/freezing) increase systematically as fear memory is acquired and decrease as fear memory is extinguished (Sotty et al., 1996; Liu et al., 2004; Apergis-Schoute et al., 2005; Davis, 2006; Erlich et al., 2012; Furini et al., 2014). Conditioned fear responses are insensitive to anxiolytic drugs (McNaughton and Corr, 2004), but several works show that treatment with diazepam, an anxiolytic drug that is widely used in the clinic, prior to the conditioning session disrupts the initial acquisition of learned fear (Jensen et al., 1979; Izquierdo and Medina, 1991; Makkar et al., 2010), decreases the occurrence of freezing responses in a dose-dependent manner in rats (Fanselow and Helmstetter, 1988; Decker et al., 1990; Beck and Fibiger, 1995; Malkani and Rosen, 2000; Isoardi et al., 2004; Yeh et al., 2015) and impairs the acquisition of conditioned suppression (Oliveira et al., 2009). Anxiolytic compounds were effective in reducing the inhibitory response of animals to an aversive stimulus, which alleviated the suppression of the CER (McNaughton and Gray, 2000; Miyamoto et al., 2000; George et al., 2009). McNaughton and col. showed that anxiolytic drugs reduced theta frequency in the hippocampus (Coop et al., 1991; Munn and McNaughton, 2008). In this sense, the sensitivity of the CER to anxiolytic drugs, such as benzodiazepines and agonists of $5-\mathrm{HT}_{1 \mathrm{~A}}$ receptors $\left(5-\mathrm{HT}_{1 \mathrm{~A}} \mathrm{Rs}\right)$ (Millenson and Leslie, 1974; Davis, 1990; Stanhope and Dourish, 1996; Mirza et al., 2005; George et al., 2009; Oliveira et al., 2009), substantiates the use of this model to investigate the fundamental mechanisms underlying the effects of anti-anxiety drugs in addition to their function in alleviating conditioned fear in rodents.

The second question concerns the neurochemical mechanisms underlying both the acquisition and the extinction of conditioned suppression, as well as the role of the flavonoidrich fraction from the stem bark of Erythrina falcata (FfB) in modulating these processes. We primarily focused on the molecular events underlying the acquisition of fear memory and the modulatory effects of FfB. Further, we were interested in determining whether treatment with flavonoids prior to 
conditioning can modulate the extinction process. Studies demonstrating the involvement of glutamatergic, serotoninergic and GABAergic neurotransmission in the acquisition of fear memory have been accumulating in past decades; the major targets of these neurotransmitters are NMDARs, $5-\mathrm{HT}_{1 \mathrm{~A}} \mathrm{Rs}$, and $\mathrm{GABA}_{\mathrm{A}} \mathrm{Rs}$, respectively (Santini et al., 2001; Davis and Myers, 2002; Lin et al., 2003; Quirk and Mueller, 2008; Kim and Richardson, 2010), and the modulation of these receptors in the hippocampus is essential for the acquisition and consolidation of fear memory (Izquierdo, 1997; Cammarota et al., 2000; Alonso et al., 2002; Milad et al., 2007). Similarly, these changes are essential to consolidation of fear extinction (Myers and Davis, 2002). These effects are mediated by the activity of kinases and phosphatases, and ERK1/2 activation has been described to be involved in several cellular changes associated with long-term memory (LTM) (Atkins et al., 1998; Cammarota et al., 2000). Blocking NMDARs in the prefrontal cortex and the hippocampus is known to result in a deficit in the acquisition of fear extinction (Lissek and Güntürkün, 2003) and the retrieval of fear extinction (Lengersdorf et al., 2014). Evidence from in vitro and in vivo studies showed that flavones modulate $\mathrm{GABA}_{\mathrm{A}} \mathrm{Rs}$ and GluN2B-NMDARs, but few studies have been conducted on the mechanisms underlying the modulatory effects of flavonoids on these processes. Therefore, in our study, we sought to elucidate the neurochemical systems involved in the acquisition of fear memory in the presence or absence of $\mathrm{FfB}$ treatment and to determine whether $\mathrm{FfB}$ treatment prior to conditioning modulates the extinction of fear memory. Further, we evaluated how these changes may control or be controlled by the activation or inhibition of specific receptors using pharmacological agonists or antagonists.

Therefore, the contributions of the glutamatergic, serotoninergic, and GABAergic systems, as well as the interactions between these systems, to the effects of $\mathrm{FfB}$ on the acquisition and extinction of conditioned suppression were assessed for the first time by administering agonists, antagonists of receptors for GABA, glutamate (NMDA) and 5-HT or one these antagonists before $\mathrm{FfB}$ prior the conditioning session. Additionally, we evaluated the mRNA expression levels of the GluN2A and GluN2B subunits of the NMDAR, the receptor subunits $\mathrm{GABA}_{\mathrm{A}} \mathrm{R}$ and $5-\mathrm{HT}_{1 \mathrm{~A}} \mathrm{R}$ and ERK1/2 in the $\mathrm{DH}$ of controls and treated rats subjected to acquisition and extinction of conditioned fear.

This combination of molecular, behavioral and pharmacological analyses advances our understanding of the role of flavones in fear memory and anxiety. The findings regarding the molecular mechanisms of flavone action appear to be promising with respect to the development of new therapeutic strategies for the treatment of cognitive deficits or anxiety disorders. Moreover, we assessed the contribution of the hippocampus to these processes. In particular, we focused on the suppression of the licking response as a behavioral model and the hippocampus as a key component of the neural circuitry involved in the acquisition, consolidation and extinction of fear memory in animals and humans, as the hippocampus may represent a target for the action of $\mathrm{FfB}$.

\section{EXPERIMENTAL PROCEDURES}

\section{Drugs and Reagents}

Methanol (HPLC grade) was obtained from Merck (Darmstadt, Germany). Formic acid, ethanol, $n$-butanol, and Tween ${ }^{\circledR}-80$ were obtained from Synth (Diadema, Brazil). Vitexin and isovitexin standards (99.99\%) were purchased from SigmaAldrich (São Paulo, Brazil). The 6-C-glycoside-diosmetin and vicenin-2 standards were generated in our laboratory according to the methods described by de Oliveira et al. (2014). Valium ${ }^{\circledR}$ (diazepam) was purchased from Roche (São Paulo, Brazil). Sintocalmy ${ }^{\circledR}$ (standardized extract of Passiflora incarnate L.extract ACH 06) was obtained from Aché (Guarulhos, Brazil). Ro25-6981, picrotoxin and (S)-WAY100135 were purchased from Tocris Biosciences (Ellisville, MO, USA). NMDA was obtained from Sigma-Aldrich (São Paulo, Brazil). Buspirone hydrochloride was obtained from LIBBS Pharmaceutical Ltd (São Paulo, Brazil).

\section{Standardized FfB Preparation}

FfB was obtained by flash chromatography, as previously described by de Oliveira et al. (2014). Additionally, the FfB was analyzed using high-performance liquid chromatography (HPLC) combined with electrospray ionization tandem mass spectrometry (HPLC-ESI/MS ${ }^{\mathrm{n}}$ ) using a Thermo LCQ Fleet System mass spectrometer (Thermo Scientific, San Diego, CA, USA) equipped with an electrospray interface (ESI) and an HPLC (model Accela, Thermo Scientific). FfB separation was performed using a Luna ${ }^{\circledR}$ C18 column $(250 \times 4.60 \mathrm{~mm}$; Phenomenex, Torrance, CA, USA) at room temperature. The mobile phase consisted of $0.1 \%$ aqueous formic acid-water (A) and methanol (B). A gradient elution method of $\mathrm{A} / \mathrm{B}$ (from 64:36 to $1: 1, \mathrm{v} / \mathrm{v}$ ) was applied over $50 \mathrm{~min}$. Ultraviolet (DAD) detection was performed at $330 \mathrm{~nm}$; the flow rate was maintained at $0.8 \mathrm{~mL} / \mathrm{min}$; the sample concentrations were 1 $\mathrm{mg} . \mathrm{mL}^{-1}$; and the injection volume was $10 \mu \mathrm{L}$. The column effluents were analyzed by ESI-MS in negative ion mode in the mass-to-charge ratio $(\mathrm{m} / \mathrm{z})$ range of 50-2000, with a scan time of $0.3 \mathrm{~s}$ in the centroid mode. The ESI conditions were as follows: nebulizer gas (nitrogen), $30 \mathrm{psi}$; drying gas, 60 L. $\mathrm{min}^{-1}$; drying temperature, $280^{\circ} \mathrm{C}$; capillary voltage, $4000 \mathrm{~V}$; collision gas, nitrogen; and collision energy, $1 \mathrm{~V}$. The data were acquired in the MS and $\mathrm{MS}^{\mathrm{n}}$ scanning modes. The $\mathrm{CE}$ was dissolved in $\mathrm{H}_{2} \mathrm{O}: \mathrm{MeOH}(1: 1 \mathrm{v} / \mathrm{v})$ and was infused directly via a syringe pump (flow rate $5 \mu \mathrm{L} \cdot \mathrm{min}^{-1}$ ) in the ESI source. The data were analyzed using Xcalibur 2.0 Software $^{\circledR}$ (Thermo Scientific).

The flavonoids present in the FfB were quantified by HPLCDAD using a Luna ${ }^{\circledR}$ C18 column (Phenomenex, Torrance, CA, USA; $250 \mathrm{~mm} \times 4.60 \mathrm{~mm}, 5 \mu \mathrm{m})$. The mobile phase consisted of $0.1 \%$ aqueous formic acid (A) and methanol (B). An isocratic elution method of A/B (64:36, v/v) was applied for $50 \mathrm{~min}$. UV spectra were recorded from 200 to $400 \mathrm{~nm}$, and the chromatogram was monitored at 254,280 , and $330 \mathrm{~nm}$. The flow rate was maintained at $1 \mathrm{~mL} \cdot \mathrm{min}^{-1}$; the sample concentration was $1 \mathrm{mg} \cdot \mathrm{mL}^{-1}$; and the injection volume was $20 \mu \mathrm{L}$. Analytical curves were obtained for vitexin, isovitexin, vicenin-2, and 
6-C-glycoside-diosmetin ( $1 \mathrm{mg} \cdot \mathrm{mL}^{-1}$ of each compound in 80:20 methanol/water), which peaked at concentrations ranging from 100 to $1.000 \mathrm{mg} \cdot \mathrm{mL}^{-1}$. The sample peak areas were integrated at $254 \mathrm{~nm}$. All of the procedures were performed in triplicate.

\section{Behavioral and Pharmacological Effects of Acute Treatment with FfB Before Conditioning on the Acquisition and Extinction of Conditioned Suppression Subjects}

A total of 470 adult male Wistar rats $( \pm 250-300 \mathrm{~g})$ were obtained from the Center for the Development of Experimental Medicine and Biology (CEDEME, Federal University of Sao Paulo, SP, Brazil). The rats were housed 5 animals/cage. For 15 days, the animals had free access to food and water under a 12 h:12 h dark:light cycle (lights on at 6:00-18:00 h) at a controlled temperature $\left(21^{\circ} \mathrm{C} \pm 2{ }^{\circ} \mathrm{C}\right)$ and relative humidity $(53 \pm 2 \%)$. These conditions were maintained throughout the experimental period. One minute prior to the experimental sessions, each rat was placed in an individual cage for transportation to the testing room. All of the procedures for manipulation of the animals were consistent with the Ethical Principles in Animal Research adopted by the Brazilian College for Animal Experimentation (COBEA) and were performed as suggested by the APA Guidelines for Ethical Conduct in the Care and Use of Animals. The protocol was approved by the Committee on the Ethics of Animal Experiments of the Federal University of Sao Paulo (Permit Number: 840560). After completion of the behavioral experiments, the animals were decapitated, and the $\mathrm{DH}$ was extracted within $40-60 \mathrm{~s}$ using a magnifying glass, immediately frozen on dry ice, and maintained at $-80^{\circ} \mathrm{C}$ until gene expression analysis. All behavioral procedures were conduced during the light phase of the dark:light cycle, and all efforts were made to minimize suffering.

\section{Systemic Administration}

Diazepam and buspirone hydrochloride (a $\mathrm{GABA}_{\mathrm{A}} \mathrm{R}$ and a 5- $\mathrm{HT}_{1 \mathrm{~A}} \mathrm{R}$ agonist, respectively), Sintocalmy ${ }^{\circledR}(\mathrm{a}$ standardized extract of Passiflora incarnata L.-extract ACH 06, containing $7 \%$ (21 mg) total flavonoids expressed as vitexin) and three different concentrations of FfB were dissolved in $12 \%$ Tween ${ }^{\circledR}$. 80 and administered orally via intragastric gavage (IG) $30 \mathrm{~min}$ before each conditioning session. The GABA $\mathrm{R}, 5-\mathrm{HT}_{1 \mathrm{~A}} \mathrm{R}$, and GluN2B-NMDAR antagonists (picrotoxin, S-WAY 100135 and Ro25-6981, respectively) and NMDA (an NMDAR agonist) were dissolved in saline and injected intraperitoneally (i.p.) $20 \mathrm{~min}$ before each conditioning session or prior to treatment with $\mathrm{FfB}$. When an antagonist was administered before with $\mathrm{FfB}$, the drugs were administered -50 or -30 min before conditioning, respectively. No drugs were administered before the retention test, extinction training or the extinction retention test. The drugs were administered i.p. or IG in a volume of $1 \mathrm{~mL}$. The doses, administration routes and vehicles used to dissolve of the antagonists and agonists were chosen based on previous reports (Aguilar et al., 1997; Risbrough et al., 2003; Oliveira et al., 2009).

\section{Experimental Procedure}

Rats were randomly assigned to the control group or the FfB group ( $n=20$ per subgroup) (Table 1 ). The control group was subdivided into 12 subgroups as follows: (i) the paired stimulus conditioned/unconditioned stimulus (CS-US) subgroup; (ii)

TABLE 1 | Experimental groups.

\section{Experimental Procedure}

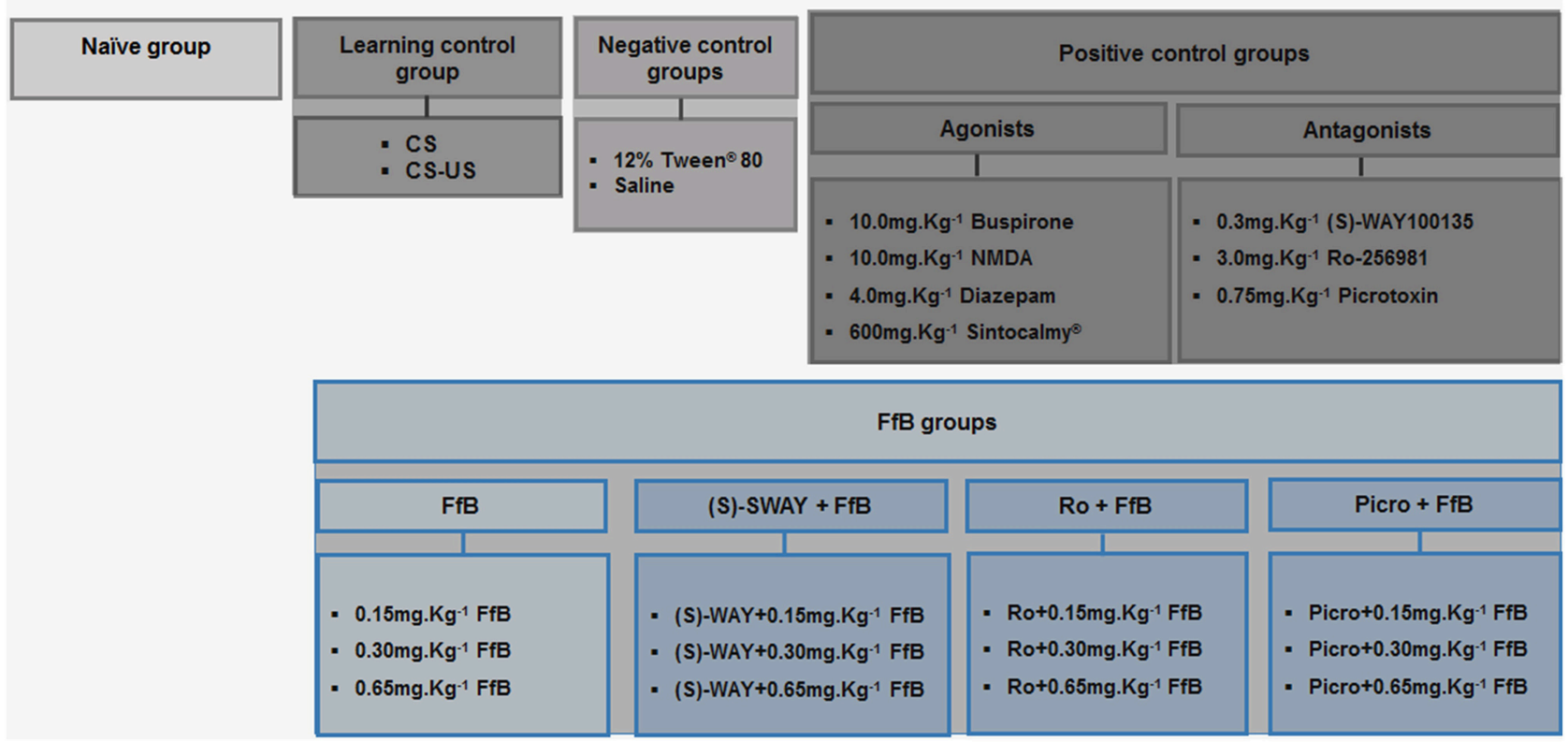


the unconditioned subgroup [no footshock, i.e., only tone (CS); as such, these animals were used as controls for learning]; (iii-iv) the negative control subgroups $\left(12 \%\right.$ Tween ${ }^{\circledR}-80$ or saline); (v-xi) the positive control subgroups $\left(4.0 \mathrm{mg} \cdot \mathrm{Kg}^{-1}\right.$ diazepam; $10.0 \mathrm{mg} . \mathrm{Kg}^{-1} \mathrm{NMDA} ; 10.0 \mathrm{mg} . \mathrm{Kg}^{-1}$ buspirone hydrochloride; $600 \mathrm{mg} . \mathrm{Kg}^{-1}$ Sintocalmy ${ }^{\circledR} ; 0.75 \mathrm{mg} \cdot \mathrm{Kg}^{-1}$ picrotoxin; $3.0 \mathrm{mg} . \mathrm{Kg}^{-1} \mathrm{Ro} 25-6981$; or $0.3 \mathrm{mg} \cdot \mathrm{Kg}^{-1}$ (S)-WAY 100135; these animals were used as controls for treatment with the respective drug together with $\mathrm{FfB}$ ); and (xvii) a naïve subgroup $(n=10)$, which was used as a control for gene expression. The FfB groups were also divided into 12 subgroups as follows: (xiii-xiv) FfB alone (0.15 mg. $\mathrm{Kg}^{-1} \mathrm{FfB}, 0.30 \mathrm{mg} \cdot \mathrm{Kg}^{-1}$ $\mathrm{FfB}$ or $0.65 \mathrm{mg} \cdot \mathrm{Kg}^{-1} \mathrm{FfB}$ ); (xv-xvii) picrotoxin+FfB (Picro+ 0.15 mg. $\mathrm{Kg}^{-1}$ FfB; Picro+0.30 mg. Kg ${ }^{-1} \mathrm{FfB}$; or Picro+0.65 mg. Kg ${ }^{-1}$ FfB); (xviii-xx) Ro25-6981+FfB (Ro+0.15 mg. Kg ${ }^{-1}$ FfB; Ro+0.30 mg. $\mathrm{Kg}^{-1} \mathrm{FfB}$ or Ro+0.65 mg. $\mathrm{Kg}^{-1} \mathrm{FfB}$ ); and (xxixxiii) (S)-WAY+FfB [(S)-WAY+0.15 mg. $\mathrm{Kg}^{-1} \mathrm{FfB}$; (S)-WAY+ $0.30 \mathrm{mg} \cdot \mathrm{Kg}^{-1} \mathrm{FfB}$ or (S)-WAY+0.65 mg. $\left.\mathrm{Kg}^{-1} \mathrm{FfB}\right]$. Half of the rats ( $n=10$ /subgroup) were sacrificed after the retention test ended. The remaining half ( $n=10$ /subgroup) were subjected to extinction training and an extinction retention test of the CER and were sacrificed $3 \mathrm{~h}$ after the conclusion of the extinction retention test.

\section{Behavioral Apparatus}

Rats were fear conditioned in a lick-operant chamber. Briefly, the experimental chambers consisted of an aluminum (side walls) and Plexiglas (ceiling and hinged front door) box measuring $25 \times 25 \times 20 \mathrm{~cm}$ set inside a sound-attenuation cabinet $(53 \times 65 \times$ $50 \mathrm{~cm}$ ). Three identical chambers and cabinets were used in all experiments. The floor consisted of stainless steel rods connected to grid shockers (model EP 107R, Insight, Ribeirão Petro, Brazil) set to deliver $0.4 \mathrm{~mA}, 0.5 \mathrm{~s}$ scrambled shocks, which were used as the US. A speaker positioned on top of the square, which produced a $2 \mathrm{kHz}, 85 \mathrm{~dB}$ sound for $30 \mathrm{~s}$, was used as the CS. A licking spout was slipped into the cage through a hole in the middle of the wall of the chamber; this hole protruded from the lateral wall $5.0 \mathrm{~cm}$ above the grid floor. Stimulus presentation and data recording were controlled using software (Refor II Software ${ }^{\circledR}$, Insight) and a central controller box (Insight). The chambers were cleaned with $10 \%$ ethanol before each test.

\section{Behavioral Procedure}

The behavioral procedure was conducted for 8 or 10 days, according to the experimental design, to assess the acquisition or extinction of a CER, respectively. All rats, except for those in the CS and naïve subgroups, were subjected to a procedure to induce acquisition of fear memory ( $n=20$ /group) (Figure 1). Three hours after the completion of the fear acquisition test ( $8^{\text {th }}$ day), half of the rats were decapitated. Then, the $\mathrm{DH}$ was extracted within 40-60 s using a magnifying glass, immediately frozen on dry ice, and maintained at $-80^{\circ} \mathrm{C}$ until gene expression analysis (acquisition analysis) ( $n=3$ /subgroup). The remaining half of the animals ( $n=10$ /subgroup) were subjected to extinction training ( $9^{\text {th }}$ day) and an extinction retention test $\left(10^{\text {th }}\right.$ day) performed on each of the two consecutive days following the acquisition test. Three hours after completing the extinction retention test, these rats were decapitated, and the $\mathrm{DH}$ was extracted as described above ( $n=3$ /group).

\section{Suppression of the licking response}

The animals were deprived of water on a daily basis for $12-16 \mathrm{~h}$ before all experimental sessions. For five consecutive days, the rats were placed individually in the chamber once a day for 20 min sessions with free access to the drinking spout to obtain a stable baseline of drinking behavior, but no other stimuli were presented (Figure 1A). After the administration of drugs or vehicle, each rat was gently placed in the experimental chamber, and after $5 \mathrm{~min}$, the animal was submitted to four toneshock (CS-US) pairings (fear conditioning, $6^{\text {th }}$ day; Figure 1B). Twenty-four hours after fear conditioning, the animals were subjected to reacquisition of the licking response sessions $\left(7^{\text {th }}\right.$ day) as performed during the acquisition of the licking response to re-establish drinking behavior after conditioning and to reduce

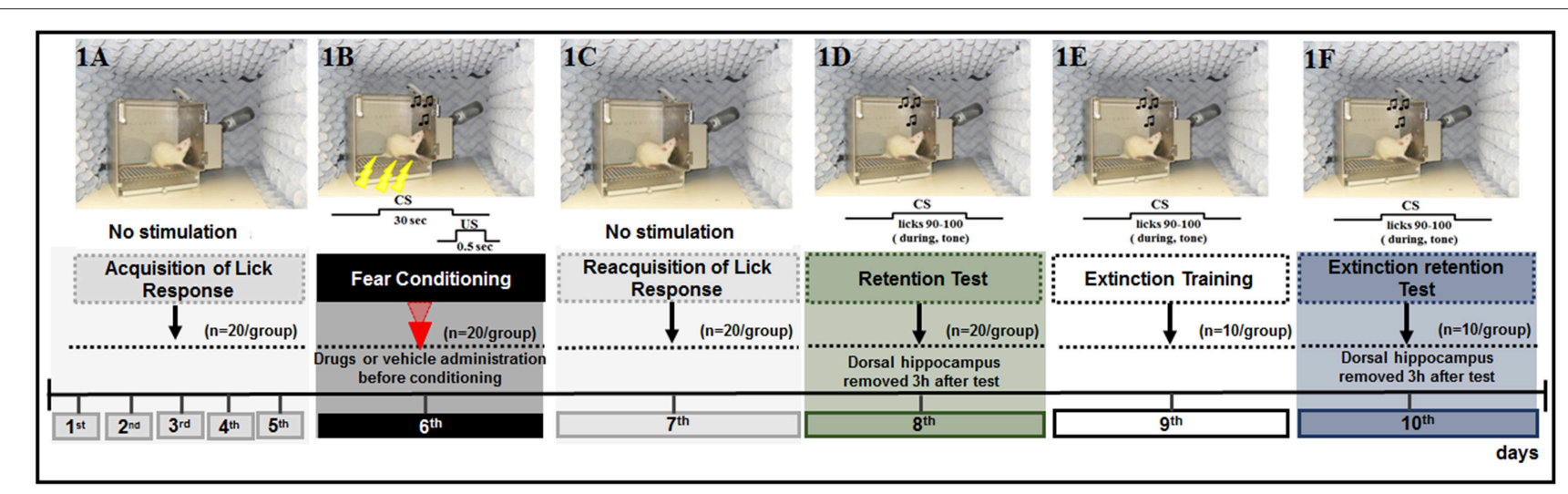

FIGURE 1 | Schematic outline of the experimental procedure and drug administration time, common to all animals, except for the CS-US, and CS groups, in which did not receive the drug or vehicle. (1A) The animals were submitted to acquisition of the licking response for 5 days (baseline behavior). (1B) On day 6, the animals were submitted to four associations of CS-US (conditioning). (1C) Twenty-four hours later (day 7), the animals were submitted to re-acquisition of licking behavior, in conditions identical to those of the acquisition period (1-5 days). Retention Test (1D), Extinction Training (1E), and Extinction Test (1F) were performed on days 8, 9, and 10, respectively. Ten CS trials were presented at these times. No drugs were administered during the tests and extinction training sessions. 
contextual cues (Figure 1C). The retention test was performed $48 \mathrm{~h}$ after acquisition ( $8^{\text {th }}$ day) to evaluate the acquisition of fear memory as well as the effects of drug treatment. Here, each rat was placed in the experimental chamber with free access to the water spout and was subjected to the CS on 10 consecutive trials, in which the time to complete 10 licks pre-tone (no CS) and during the tone (CS) were recorded, and the suppression ratio (SR) was calculated for each trial. The tone was presented immediately after the animal completed its $90^{\text {th }}$ lick and was switched off after its $100^{\text {th }}$ lick (Figure 1D). The latency to complete licks $0-80$ was recorded to ensure that the rats were licking when the tone was presented, but this value was not used to calculate the suppression of the lick response. The latency to complete licks 81-90 was measured as a control for time in the absence of a tone and was used to calculate the SR.

Therefore, the SR was calculated as the ratio of $B /(A+B)$ for each rat, where $\mathrm{A}$ is the time to complete 10 licks pre-tone (pre-CS), i.e., time to complete licks $81-90$ and B is the time to complete 10 licks during the CS, i.e., time to complete licks 91-100.

\section{Extinction of suppression of the licking response}

Analysis of the effects of FfB on extinction was performed using the behavioral protocol described for acquisition. All rats were subjected to tests of adaptation $\left(1^{\text {st }}-5^{\text {th }}\right.$ days $)$, acquisition $\left(6^{\text {th }}\right.$ day), reacquisition ( $7^{\text {th }}$ day), and retention of the CER ( $8^{\text {th }}$ day). Seventy-two hours $\left(9^{\text {th }}\right.$ day) and ninety-six hours $\left(10^{\text {th }}\right.$ day) after fear conditioning, the rats were placed in the experimental chamber for extinction training and extinction test sessions, respectively (Figures 1E,F). In both sessions, the latencies to complete licks before the tone and during the tone for 10 consecutive CS presentations were recorded as described for the $8^{\text {th }}$ day.

\section{Data Analysis}

The data from the first CS presentation indicated whether the association was learned. An SR approaching 1.0 indicates total suppression (high fear), whereas an $\mathrm{SR} \leq 0.5$ indicates no suppression (low fear), i.e., failure to learn the tone-shock relationship. The data are reported as the means \pm SEM. A Twoway analysis of variance (ANOVA) was used to test for the presence of the effects of group and trial and the interaction between these variables; two fixed factors (group and trial), one random factor (rat), and repeated measurement of the trials were considered. $P<0.05$ were considered significant. Graph Pad 6.0 Software ${ }^{\circledR}$ (version 6.0; Graph Pad Inc., San Diego, CA, USA) was used for data analysis.

\section{Expression of Gabra5, Htr1a, Grin2a, Grin2b, and Mapk1/Erk2 by Quantitative PCR (qPCR) Following Treatments Before Conditioning and Behavioral Analysis}

The analysis of gene expression in the $\mathrm{DH}$ samples was extracted $3 \mathrm{~h}$ after the completion of the retention test or the extinction retention test as previously described. The candidate genes gamma-aminobutyric acid receptor subunit alpha-5 (Gabra5), 5-hydroxytryptamine (serotonin) receptor, subunit
1A (Htr1a), glutamate receptor ionotropic, NMDAR subunit GluN2A (Grin2a), glutamate receptor ionotropic, NMDAR subunit GluN2B (Grin2b), and extracellular signal-regulated kinase 2 (Erk2) were investigated. To this end, total RNA was isolated using Trizol reagent (Invitrogen Corp., Carlsbad, CA, USA) according to the manufacturer's recommendations. One microgram of total RNA was subjected to DNA-free DNase treatment (AMBION, Austin, TX, USA) and reverse-transcribed into cDNA using the SuperScript ${ }^{\circledR}$ III Reverse Transcriptase kit (Invitrogen Corp.) together with oligo ${ }_{12-18}$ primer and 10 units of an RNase inhibitor (Invitrogen Corp.). Reverse transcriptasenegative samples were prepared for each individual reaction and were used as controls for assay contamination. Aliquots of $1 \mu \mathrm{L}$ of cDNA were used in $12 \mu \mathrm{L}$ reactions containing SYBR Green Master Mix (PE Applied Biosystems, Foster City, CA) and 3pM of each primer for the target genes and the reference gene (RS8) as described previously (Cerutti et al., 2004). The primer sequences are displayed in (Table S1). The qPCR reactions were performed in triplicate, and the threshold for each cycle $(\mathrm{Ct})$ was obtained using Applied Biosystems software (Applied Biosystems) and averaged [standard deviation $(\mathrm{SD}) \leq 1$ ]. Relative expression $(\mathrm{RE})$ levels were calculated using the $2^{-\bar{\triangle} \triangle \mathrm{CT}}$ method (ddCt formula) as described previously (Cerutti et al., 2004). The vehicle (12\% Tween ${ }^{\circledR}-80$ or saline) was used as a control.

The analyses were performed using Graph Pad 6.0 Software ${ }^{\circledR}$ (version 6.0; Graph Pad Inc., San Diego, CA, USA). For candidate gene expression analysis, normality of the data was verified using the Shapiro-Wilk normality test. One-way ANOVA followed by a post-hoc Bonferroni test was performed to evaluate the relationships between the expression levels of Gabra5, Htrla, Grin2a, Grin2b, and Erk2 across groups. $P<0.05$ were considered significant.

\section{RESULTS}

\section{Identification of Flavonoids in FfB}

The spectroscopic and chromatographic data of the peaks (16) of the FfB are summarized in Figures S1A,B. The identities, fragmentation patterns and UV spectra were confirmed as follows: (1) vicenin-2: $\lambda \max =334,271 \mathrm{~nm},[\mathrm{M}-\mathrm{H}]^{-}=\mathrm{m} / z$ 593; (2) vicenin-1: $\lambda \max =332,271 \mathrm{~nm},[\mathrm{M}-\mathrm{H}]^{-}=m / z 563$; (3) vitexin: $\lambda \max =269,235 \mathrm{~nm},[\mathrm{M}-\mathrm{H}]^{-}=m / z$ 431; (4) isovitexin: $\lambda \max =335,271 \mathrm{~nm},[\mathrm{M}-\mathrm{H}]^{-}=m / z 431$; (5) 6-Cglycoside-diosmetin: $\lambda \max =342,270 \mathrm{~nm},[\mathrm{M}-\mathrm{H}]^{-}=m / z 461$; and (6) apigenin: $\lambda \max =305,265 \mathrm{~nm},[\mathrm{M}-\mathrm{H}]^{-}=\mathrm{m} / z 269$. These results were consistent with those previously reported by de Oliveira et al. (2014). The identification of 6-C-glycosidediosmetin, vicenin-2, vitexin and isovitexin was supported by the co-injection of the standards and FfB. The flavones $(1,3$, 4, and 5) found in the FfB were quantified by HPLC-DAD, and the concentrations contained in the $\mathrm{FfB}$ were $0.15 \mathrm{mg} / \mathrm{g}$ vicenin-2, $0.20 \mathrm{mg} / \mathrm{g}$ vitexin, $0.30 \mathrm{mg} / \mathrm{g}$ isovitexin, and $0.25 \mathrm{mg} / \mathrm{g}$ 6-C-glycoside-diosmetin.

Despite the evidence from our studies, few studies have examined the effects of a flavonoid fraction on fear memory. Further, previous data from our group suggest that the FfB may modulate different neurochemical systems. 


\section{Behavioral, Pharmacological, and Molecular Analysis}

The timelines illustrating the time points of drug administration and of brain removal are shown in Figures $2 \mathbf{A}, 3 \mathbf{A}, \mathbf{4 A}$ and 5A. The effects of treatment with $\mathrm{FfB}$ and with agonists and antagonists specific to $5-\mathrm{HT}_{1 \mathrm{~A}}$ Rs, GluN2B-NMDARs, and $\mathrm{GABA}_{\mathrm{A}}$ Rs or antagonists before $\mathrm{FfB}$ on the acquisition and extinction of the suppression of the licking response were assessed according to the mean SR for each tone, measured across 10 trials Figures $2 B, 3 B, 4 B$ and $5 B$. Every figure shows the mean SRs for the CS on the first trial and each three-trial block from the retention test, extinction training, and extinction retention test sessions. The first trial is presented independently because it represents the first presentation of the CS after conditioning, extinction training, or retrieval of extinction; thus, the results from this trial can characterize the level of fear of the animal in each situation. In addition, the results from the first trial can show (i) the duration of fear memory expression and (ii) the occurrence of spontaneous recovery. The means $( \pm$ SEM) for each first trial

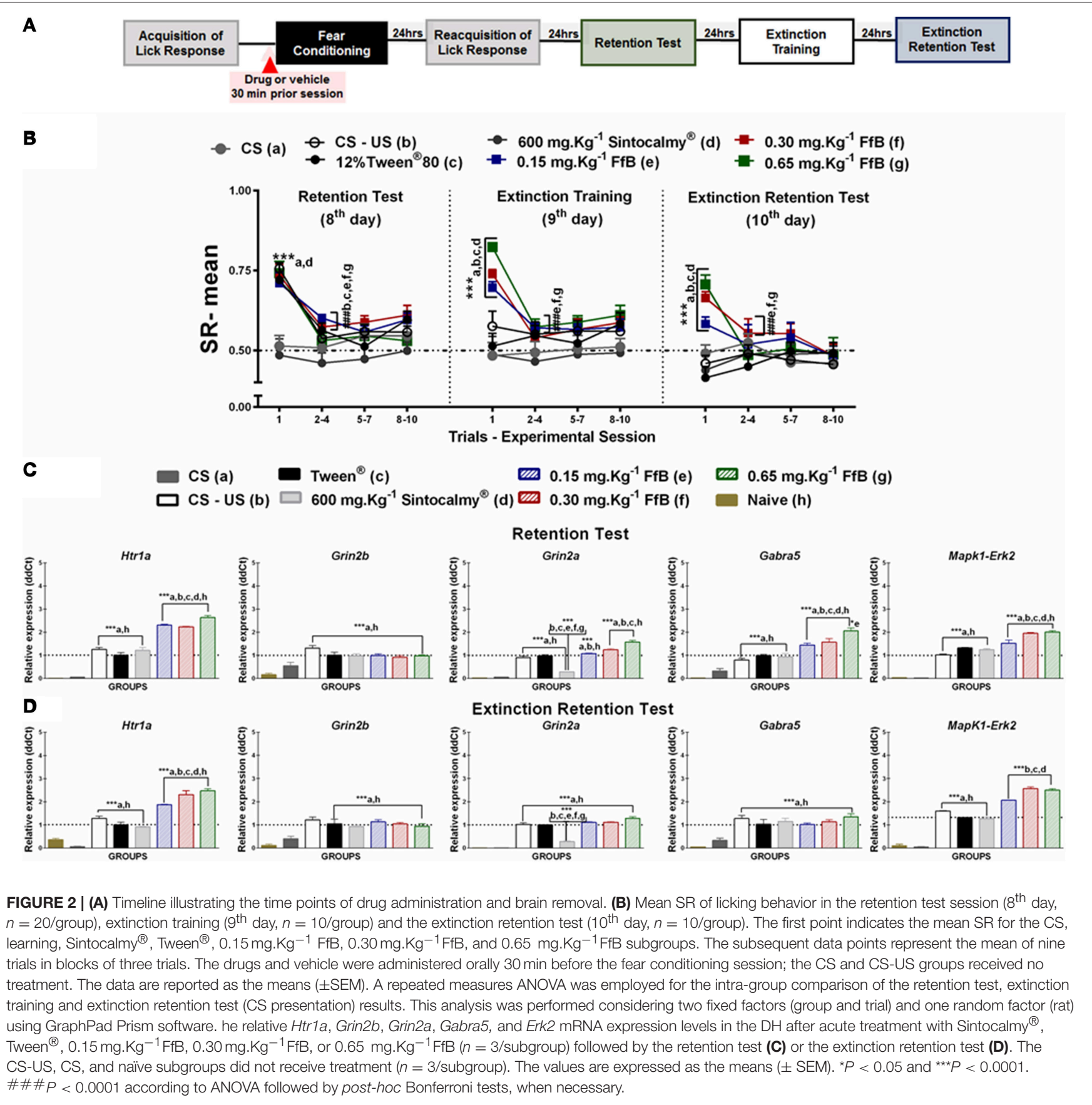




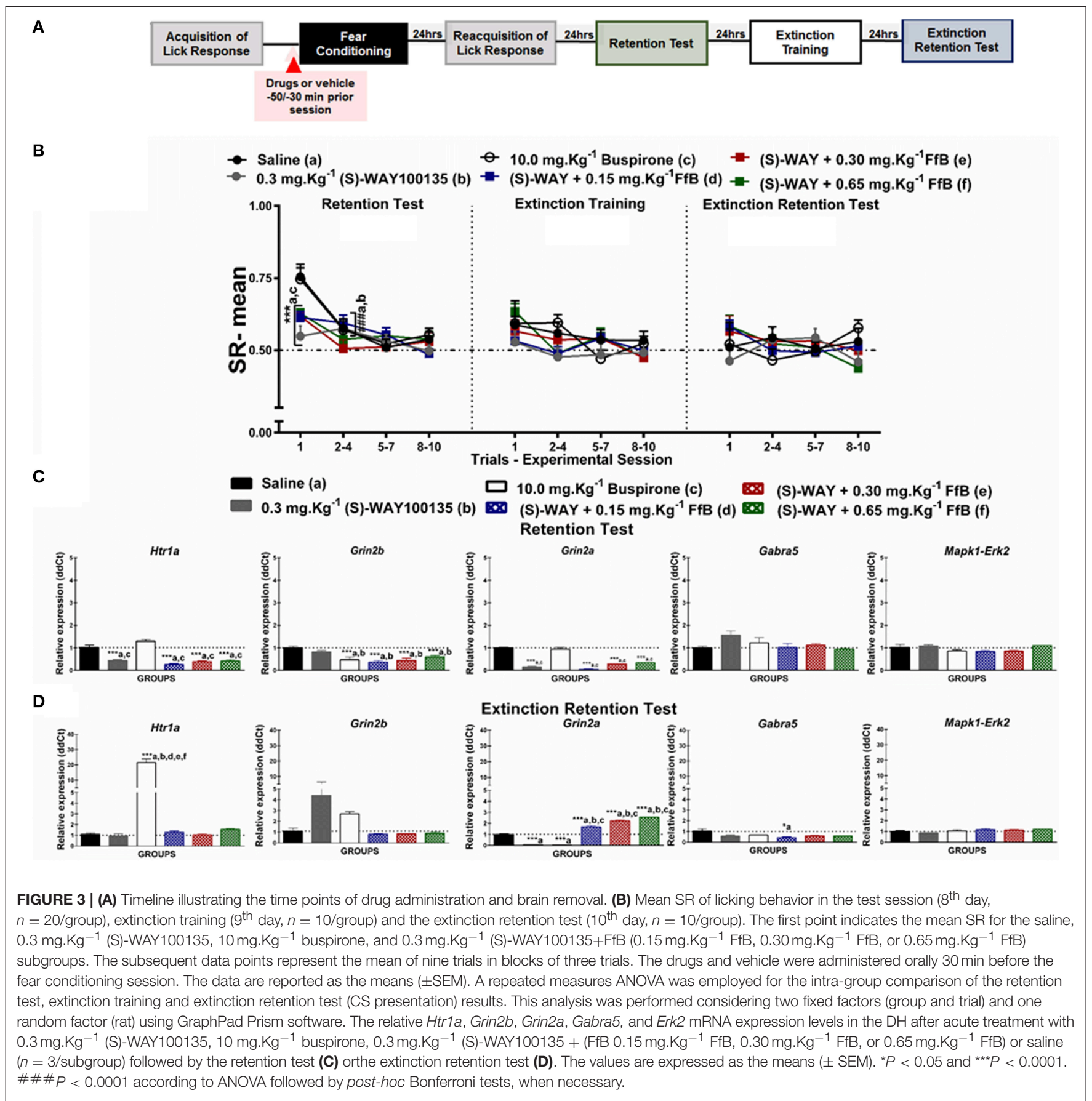

and block of three trials are presented in Tables S2, S4, S6 and $S 8$.

To investigate the molecular mechanisms involved in modulating the suppression of the licking response by $\mathrm{FfB}$, the expression levels of Grin2a, Grin2b, Gabra5, Htr1a, and Erk2 in the DH were assayed by qRT-PCR. The effects of $\mathrm{FfB}$, agonists and antagonists specific to the glutamatergic, serotoninergic and GABAergic systems were evaluated $3 \mathrm{~h}$ after the retention test session $\left(8^{\text {th }}\right.$ day; Figures $2 \mathrm{C}, 3 \mathrm{C}, 4 \mathrm{C}$ and $5 \mathrm{C})$ and the extinction retention test session $\left(10^{\text {th }}\right.$ day;
Figures 2D, 3D, 4D and 5D). The mean \pm SEM values for the $\mathrm{RE}$ of candidate genes (ddCt) are available in Tables S3, S5, S7, S9.

Further, we have made statistical comparison between control groups, which received the vehicle solutions (Saline and Tween ${ }^{\circledR}$ ). To comparison of SR means during all trial of presentation of CS we used Paired $t$-test. No statistically significant difference was found between-session or intra-session $(P=0.1450)$. To comparisons of differential gene expression from samples of $\mathrm{DH}$, we have used unpaired $T$-test. Comparisons 


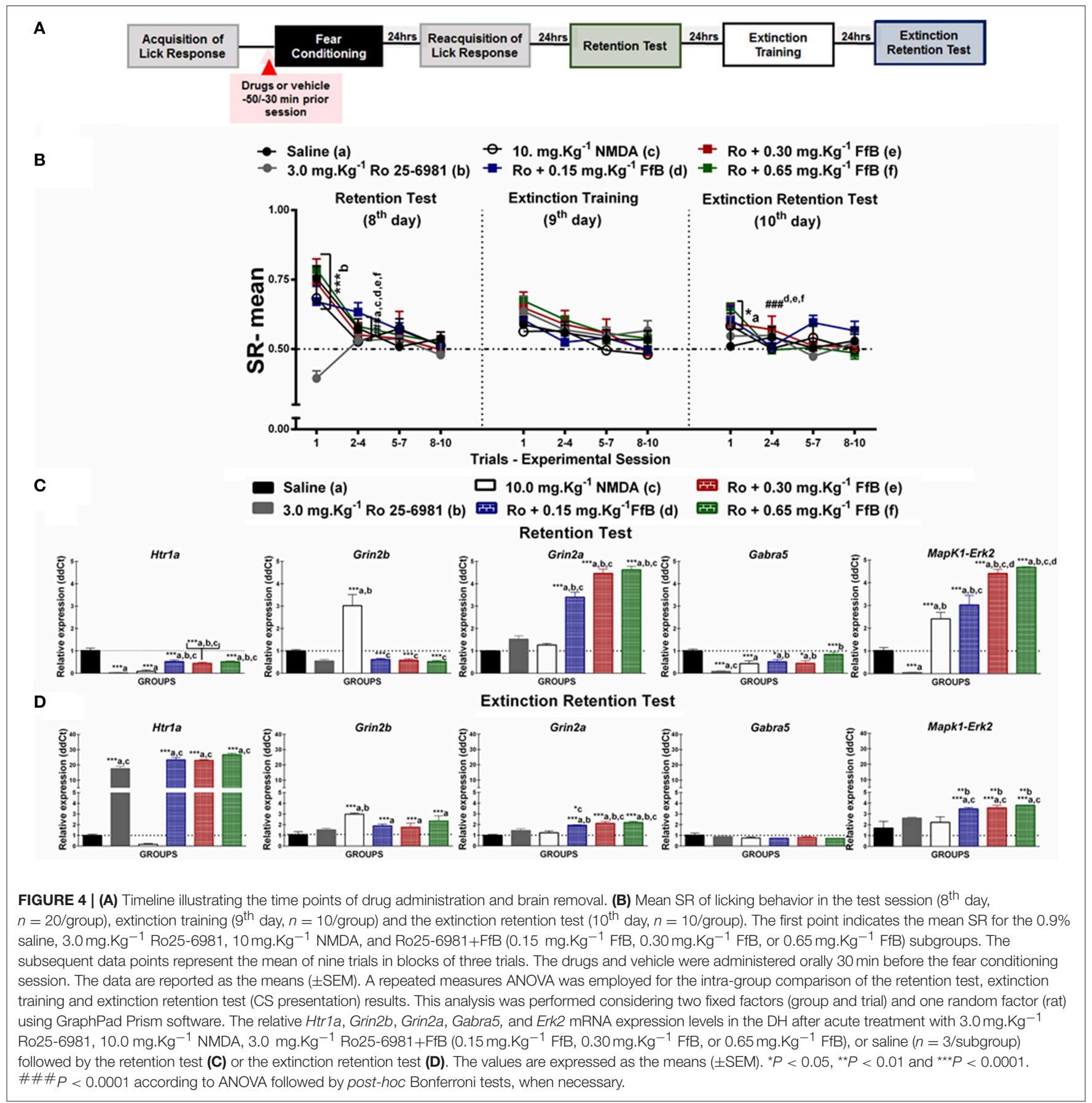

between Saline and Tween ${ }^{\circledR}$ groups, after retention test $\left(8^{\text {th }}\right.$ day), were made to each gene evaluated. No significant difference was observed in the RE levels of Htrla $(P=0.9737)$, Grin $2 b$ $(P=0.9691)$, Gabra5 $(P=0.9592)$, Grin2a $(P=0.7358)$, or Erk2 $(P=0.0962)$. Comparisons between Saline and Tween ${ }^{\circledR}$ groups, after extinction retention test $\left(10^{\text {th }}\right.$ day), were made to each gene evaluated, similarly to aforementioned, no significant difference between groups was observed in the RE levels of Htrla $(P=0.5834)$, Grin2b $(P=0.9208)$, Gabra5 $(P=0.9982)$, Grin $2 a$ $(P=0.9628)$, or $\operatorname{Erk2}(P=0.1469)$.

\section{Effects of FfB on the Acquisition and Extinction of Suppression of the Licking Response}

The effects of FfB on the acquisition and extinction of suppression of the licking response are shown in Figure $2 \mathbf{B}$ and Table S2. A Two-way ANOVA revealed a significant group $\times$ trial interaction $\left[F_{(66,756)}=2.785, P<0.0001\right]$, a main effect of group $\left[F_{(66,756)}=24.56, P<0.0001\right]$ and a main effect of trial $\left[F_{(11,756)}=17.27, P<0.0001\right]$.

Comparisons of the results for the first trial in the retention test sessions between groups revealed elevated SR in the 


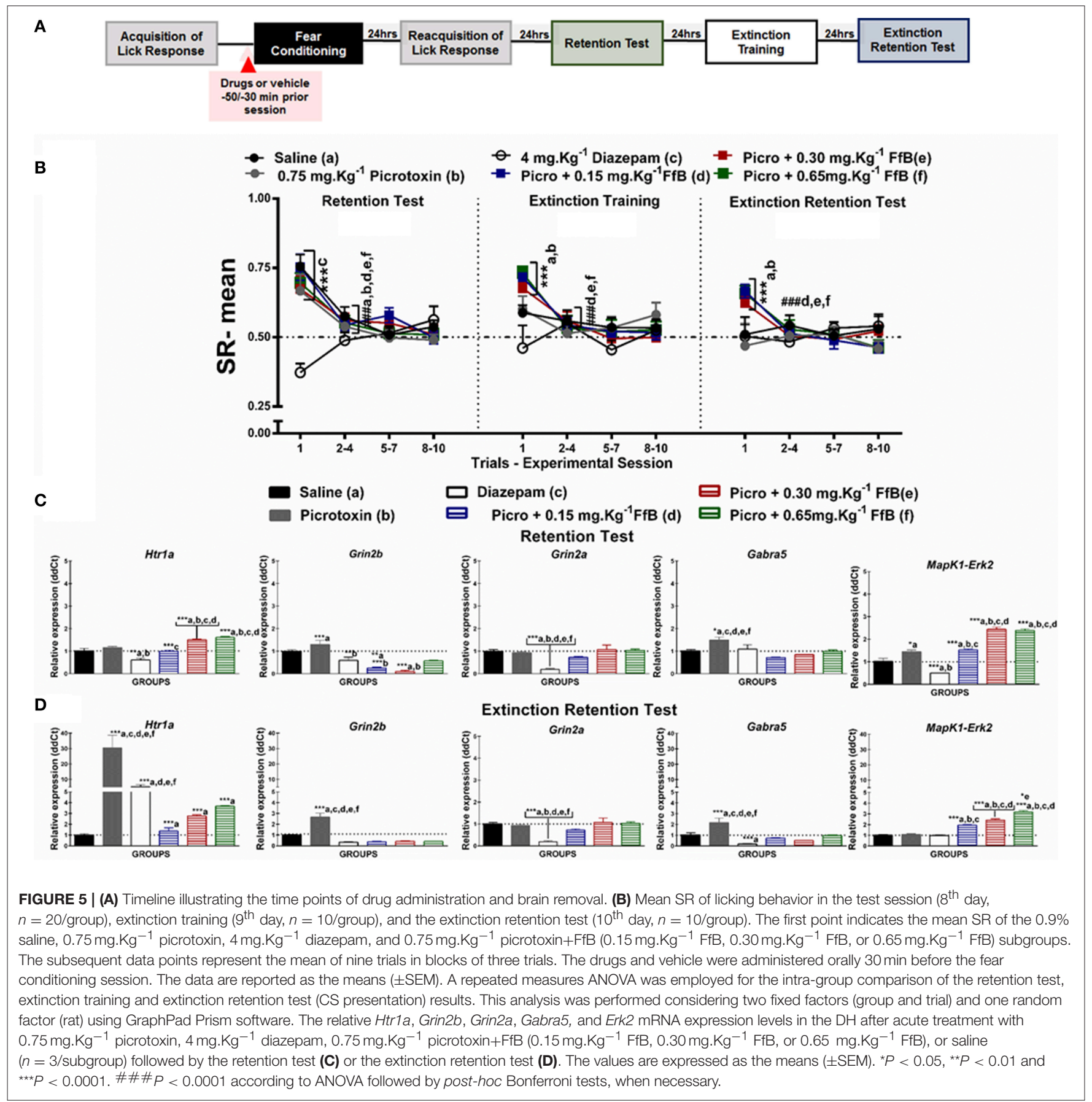

subgroups treated with FfB, CS-US or Tween and reduced SR in the subgroups treated with Sintocalmy ${ }^{\circledR}$ or CS $(P<0.0001$; left panel of Figure 2B). The analysis of SR in the first threetrial block ( $2^{\text {nd }}-4^{\text {th }}$ trials) showed a significant decrease in mean SR relative to the first trial in the Tween ${ }^{\circledR}$, CS-US, and FfB subgroups $(P<0.0001)$; these results indicated the acquisition of extinction of fear memory within the session. An ANOVA comparing the three-trial blocks revealed no differences within sessions $(P>0.05)$. This finding indicated a reliable decrease in suppression and a reduction of fear after each session.
The middle panel of Figure $2 \mathbf{B}$ depicts the data from the extinction training session conducted $24 \mathrm{~h}$ after the retention test. Treatment with $\mathrm{FfB}$ at all doses promoted spontaneous recovery, as demonstrated by the results for the first trial in each subgroup, compared to treatment with Tween ${ }^{\circledR}$ or Sintocalmy ${ }^{\circledR}$ or to CS or CS-US alone. However, in subsequent trials, rats treated with $\mathrm{FfB}$ acquired fear extinction within the session $(P<0.0001)$. The Tween ${ }^{\circledR}$ and CS-US subgroups exhibited a similar SR mean across successive exposures to the CS during the extinction training session, as observed in the retention test. The 
Sintocalmy ${ }^{\circledR}$ and CS subgroups showed mean SRs during all CS presentations that were similar to those measured in the retention test $(P>0.05)$. This result indicated no conditioned fear and, as a consequence, no acquisition of fear extinction.

The right panel of Figure $2 \mathbf{B}$ shows the mean SRs in the extinction retention session conducted $24 \mathrm{~h}$ after extinction training. The subgroups treated with FfB exhibited spontaneous recovery in the first trial, similar to the behavior observed during the extinction training session. However, all subgroups exhibited similar behavior by the end of the session. Notably, for the first trials, the mean SRs for each subgroup treated with FfB were significantly different from those for the Tween ${ }^{\circledR}$ and CS subgroups $(P<0.0001)$. Comparisons between the first trial and the first three-trial block (2-4) showed reduced suppression of the licking response in the Tween ${ }^{\circledR}$, CS-US and all FfB subgroups $(P<0.0001)$. An ANOVA comparing the results for the three-trial blocks within the session demonstrated no significant differences in the mean SR between the subgroups $(P>0.05)$. In addition, no significant differences in the mean SR were observed in the CS subgroup across all sessions $(P>0.05)$.

In summary, our data show for the first time that FfB does not impair the conditioned fear. However, rats treated with FfB showed spontaneous recovery of fear conditioning, as observed in the extinction training and extinction retention test sessions, although $\mathrm{FfB}$ did not prevent the acquisition within-session extinction. Furthermore, acute treatment with Sintocalmy ${ }^{\circledR}$, a standardized extract containing $7 \%$ of the total flavonoids expressed in vitexin, impaired the conditioned fear and, consequently, resulted in no acquisition of the extinction of fear conditioning.

\section{FfB Treatment Modulates the Spontaneous Recovery of Fear Memory via Htr1a and Erk2 Expression Within the $\mathrm{DH}$}

FfB treatment at three different doses resulted in the overexpression of Htrla $\left[F_{(7,16)}=173.0, P<0.0001\right]$, $\operatorname{Grin} 2 a\left[F_{(7,16)}=165.2, P<0.0001\right]$, Gabra5 $\left[F_{(7,16)}=40.82\right.$, $P<0.0001]$, and $\operatorname{Erk} 2\left[F_{(7,16)}=155.5, P<0.0001\right]$ in the $\mathrm{DH}$ after the retention test session $\left(8^{\text {th }}\right.$ day) compared with the control treatments $\left(\right.$ Tween ${ }^{\circledR}$, Sintocalmy ${ }^{\circledR}$, CS-US, CS, and naïve; Figure 2C). The Htr1a, Grin2b, Grin2a, Gabra5, and Erk2 expression levels were increased in the control subgroups (Tween ${ }^{\circledR}$ and CS-US subgroups) compared with the CS and naïve subgroups $(P<0.0001)$. No difference was observed in $\operatorname{Grin} 2 b\left[F_{(7,16)}=13.97\right]$ expression after treatment with FfB compared to the treatment with FfB and CS-US groups $(P>0.05$; Figure 2C and Table S3), and Grin2a expression decreased after treatment with Sintocalmy ${ }^{\circledR}(P<0.0001)$.

In the extinction retention test, $\operatorname{Htrla}\left[F_{(7,16)}=96.39\right]$ and $\operatorname{Erk} 2\left[F_{(7,16)}=388.9 ; P<0.0001\right]$ expression was significantly increased after $\mathrm{FfB}$ treatment in the $\mathrm{DH}$ compared with all other treatments $(P<0.0001$; Figure 2D and Table S3). No significant difference in the RE levels of $\operatorname{Grin} 2 b\left[F_{(7,16)}=12.20\right]$, Gabra5 $\left[F_{(7,16)}=16.11\right]$, or Grin2a $\left[F_{(7,16)}=181.6\right]$ was observed in the FfB-treated subgroups compared to the CS-US or Tween ${ }^{\circledR}$ subgroups $(P>0.05)$, although these expression levels were increased compared to the CS and naïve subgroups
$(P<0.05)$. Furthermore, Grin $2 a$ expression was reduced following the extinction retention test due to treatment with Sintocalmy ${ }^{\circledR}$ compared with all other treatments (Tween ${ }^{\circledR}$ and CS-US treatments; $P<0.0001)$.

In summary, the acquisition and extinction of the suppression of the licking response modulated Htr1a, Grin $2 b$, Grin $2 a$, Gabra5, and Erk2 expression, and FfB treatment altered Htr1a, Grin2a, Gabra5, and Erk2 expression after the retention test. Furthermore, the spontaneous recovery of fear memory appears to correlate with the overexpression of Htrla and Grin $2 a$ in the $\mathrm{DH}$.

\section{Effects of FfB on Fear Memory After Blocking $5-\mathrm{HT}_{1 \mathrm{~A}} \mathrm{Rs}$}

Figure 3B illustrates the specific effects of blocking 5$\mathrm{HT}_{1 \mathrm{~A}} \mathrm{Rs}$ before $\mathrm{FfB}$ treatment, which was administered before conditioning, on the results for the retention test, extinction training, and the extinction retention test. A Twoway ANOVA revealed a significant trial $\times$ group interaction $\left[F_{(55,648)}=1.365, P=0.0453\right]$, a main effect of group $\left[F_{(5,648)}=2.792, P=0.0166\right]$ and a main effect of trial $\left[F_{(11,648)}=9.116, P<0.0001\right]$. Similar mean SRs were observed between the Tween and saline groups across sessions $(P>0.05)$. Therefore, saline was used to compare the effects of antagonists and agonists together with FfB.

The left panel of Figure 3B shows the mean SRs in the $\mathrm{CS}$, negative control (saline), positive control $\left(0.30 \mathrm{mg} \cdot \mathrm{Kg}^{-1}\right.$ (S)-WAY100135 and $10.0 \mathrm{mg} \cdot \mathrm{Kg}^{-1}$ buspirone), and treated subgroups $\quad\left[0.30 \quad \mathrm{mg} \cdot \mathrm{Kg}^{-1} \quad(\mathrm{~S})-\mathrm{WAY}+\mathrm{FfB} \quad\left(0.15 \mathrm{mg} \cdot \mathrm{Kg}^{-1}\right.\right.$; $0.30 \mathrm{mg} \cdot \mathrm{Kg}^{-1}$; or $\left.\left.0.65 \mathrm{mg} \cdot \mathrm{Kg}^{-1} \mathrm{FfB}\right)\right]$ for the retention test session. The analysis of mean SR for the first trial showed that treatment with (S)-WAY100135 or (S)-WAY100135 before FfB resulted in reduced suppression of the licking response compared with saline $(P<0.0001)$ and buspirone treatment $(P<0.0001)$. Analysis of the SR for the first three-trial block $\left(2^{\text {nd }}-4^{\text {th }}\right.$ trials $)$ showed significant differences in the mean SRs compared to the first trial in the saline and buspirone subgroups $(P<0.0001)$. This result demonstrates acquisition within-session extinction to these subgroups. Alternatively no such differences were observed in the (S)-WAY100135 or (S)-WAY+FfB subgroups $(P>0.05)$. An ANOVA comparing the first three-trial block (2-4) with the subsequent three-trial blocks (5-7 and 8-10) demonstrated no significant differences in mean SR on the extinction retention session between the subgroups ( $P>0.05$; see Table S4).

The data from the extinction training tests are shown in the middle panel of Figure 3B. Comparisons between groups showed that the groups treated with (S)-WAY+FfB, at all doses, did not demonstrate a difference in the mean SR $(P>0.05)$. Analysis of the mean SR during the first three-trial block (2-4) showed that rats treated with $(S)-W A Y+F f B$, saline, buspirone or $(S)$ WAY100135 exhibited a similar mean SR to that in the first trial $(P>0.05)$. Moreover, similar mean SRs were observed with in all groups for the subsequent three-trial blocks (5-7 and 8-10; $P>0.05$; see also Table S4).

The data from the extinction retention tests are shown in the right panel of Figure 3B. The analysis of the SR showed that the subgroups treated with (S)-WAY100135+FfB did not 
exhibit spontaneous recovery. Furthermore, the analysis of the mean SR showed no significant difference between the first three-trial block $\left(2^{\text {nd }}-4^{\text {th }}\right.$ trial $)$ and the first trial among the (S)-WAY100135+FfB subgroups at all doses $(P<0.0001)$. Therefore, no significant differences in mean SRs were found among the subgroups between the first three-trial block (2-4) and the subsequent three-trial blocks $(5-7$ and $8-10 ; P>0.05$; see Table S4).

A Two-way ANOVA comparison between groups treated with FfB vs. (S)-WAY100135+FfB revealed a significant groups $\times$ trial interaction $\left[F_{(55,495)}=2.018, P<0.0001\right]$ and main effects of trial $\left[F_{(11,99)}=21.25, P<0.0001\right]$ and groups $\left[F_{(5,45)}=21.41\right.$, $P<0.0001]$. Treatment with (S)-WAY100135+ $030 \mathrm{mg} \cdot \mathrm{Kg}^{-1}$ $\mathrm{FfB}$ and (S)-WAY100135+ $065 \mathrm{mg} \cdot \mathrm{Kg}^{-1} \mathrm{FfB}$, resulted in reduced of licking response compared with $\mathrm{FfB}$ group in the first trial during extinction training. No significant difference was observed among subsequent three-trial blocks. Furthermore, the analysis of the mean SR showed significant difference between (S)-WAY100135 + 0.65 mg. $\mathrm{Kg}^{-1} \mathrm{FfB}$ and $0.65 \mathrm{mg} \cdot \mathrm{Kg}^{-1} \mathrm{FfB}$ to the first trial during extinction retention test $(P<0.0001)$. No significant difference was observed among subsequent three-trial blocks.

In summary, our data demonstrate that (S)-WAY+FfB, at all doses, reduces the suppression of the licking response compared with the control treatment, as demonstrated by the results from the retention test. These data suggest for the first time that the spontaneous recovery observed in the $\mathrm{FfB}$ subgroups is modulated by $5-\mathrm{HT}_{1 \mathrm{~A}} \mathrm{Rs}$.

\section{(S)-WAY100135 Treatment Prevents the Overexpression of Htr1a and Erk2 Within the DH Caused by FfB}

We used treatment with (S)-WAY100135 prior to FfB administration to assess the role of the $5-\mathrm{HT}_{1 \mathrm{~A}} \mathrm{R}$ in the acquisition and extinction of fear memory. In addition, the roles of NMDARs, GABA $\mathrm{R}_{\mathrm{S}}$, and ERK2 were evaluated.

Figure 3C shows the levels of Htr1a, Gabra5, Grin2a, Grin $2 b$, and Erk2 expression in the $\mathrm{DH}$ after the retention test session ( $8^{\text {th }}$ day). Consistent with the results of Htrla and Erk2 expression after FfB administration, treatment with (S)$\mathrm{WAY} 100135+\mathrm{FfB}$, at all doses, resulted in the downregulation of Htr1a expression $\left[F_{(5,12)}=449.9, P<0.0001\right]$. Treatment with (S)-WAY100135+FfB resulted in the downregulation of Htrla expression when compared with saline and buspirone treatment $\left[F_{(5,12)}=40.05, P<0.0001\right]$. Although Erk2 expression was similar across all groups $\left[F_{(5,12)}=3.071\right.$, $P=0.0516]$. A ANOVA comparison between the groups treated with (S)-WAY100135+FfB vs. FfB revealed that the overexpression of Erk2 observed after FfB treatment was reversed by (S)-WAY100135 pretreatment, at all doses $\left[F_{(5,12)}=57.79\right.$, $P<0.0001]$. Furthermore, (S)-WAY100135+FfB induced the downregulation of Grin $2 a\left[F_{(5,12)}=124.8\right]$ and Grin $2 b$ $\left[F_{(5,12)}=8.794 ; P=0.001\right]$ expression compared with saline and buspirone $(P<0.0001)$. Moreover, (S)-WAY100135 treatment decreased the expression of Grin $2 a$, but not Grin $2 b$, and buspirone treatment reduced Grin $2 b$ expression compared with saline treatment $(P<0.0001)$. No significant changes in
Gabra5 expression were observed $\left[F_{(5,12)}=2.505, P=0.0894\right]$. These statistics are shown in Table S5.

Figure 3D shows Htr1a, Gabra5, Grin2a, Grin2b, and Erk2 expression in the $\mathrm{DH}$ after the extinction retention test $\left(10^{\text {th }}\right.$ day). These data show that treatment with (S)-WAY100135 before FfB administration, at three different doses, resulted in the overexpression of Grin $2 a\left[F_{(5,12)}=278.4, P<0.0001\right]$ compared with the control treatments [saline, buspirone, and (S)WAY100135] and in the downregulation of Gabra5 compared to treatment with $0.15 \mathrm{mg} \cdot \mathrm{Kg}^{-1} \mathrm{FfB}\left[F_{(5,12)}=4.338, P=0.0174\right]$. Additionally, treatment with (S)-WAY100135+FfB resulted in the downregulation of $\operatorname{Htrla}\left[F_{(5,12)}=31.18, P<0.0001\right]$, Erk2 $\left[F_{(5,12)}=119.9, P<0.0001\right]$ and Gabra5 expression $\left[F_{(5,12)}=20.48, P<0.0001\right]$ and overexpression of Grin $2 a$ in the $\mathrm{DH}\left[F_{(5,12)}=82.00, P<0.0001\right]$. Furthermore, treatment with buspirone resulted in the upregulation of Htrla expression $\left[F_{(5,12)}=72.92 ; P<0.001\right]$ compared with all other treatments. Nevertheless, no significant differences were observed in the RE of $\operatorname{Grin} 2 b\left[F_{(5,12)}=3.039, P=0.0010\right]$ or Erk2 $\left[F_{(5,12)}=\right.$ 2.94, $P=0.0580]$. Treatment with (S)-WAY100135 prior to FfB administration, at all three doses, prevented the upregulation of Htrla expression observed after FfB treatment (Figure 2D; see also Table S5).

In summary, our data show that treatment with (S)WAY 100135 prior to FfB administration decreases Htr1a, Grin2b, and Grin $2 a$ expression in the $\mathrm{DH}$ after the retention test and prevents the increase in Htr1a and Erk2 expression after the extinction retention test in relation to observed after treatment with FfB alone. Conversely, Grin $2 a$ expression in the $\mathrm{DH}$ was increased after (S)-WAY100135+FfB treatment after the extinction retention test compared with $\mathrm{FfB}$ treatment.

\section{Effects of FfB on Fear Memory After Blocking GluN2B-NMDARs}

Figure 4B shows the effects of specifically blocking GluN2BNMDARs with Ro25-6981 before FfB treatment, which was administered before conditioning, on the results from the retention test, extinction training and the extinction retention test. A Two-way ANOVA revealed a significant trial $\times$ group interaction $\left[F_{(55,648)}=2.170, P<0.0001\right]$, a main effect of group $\left[F_{(5,648)}=3.356, P<0.0001\right]$ and a main effect of trial $\left[F_{(11,648)}=11.57, P<0.0001\right]$.

The left panel of Figure 4B shows the mean SRs for the retention test session. Comparisons of the mean SR on the first trial revealed a difference between the Ro25-6981treated subgroup and all other subgroups $(P>0.0001)$; this result indicated that blockade of GluN2B impaired the acquisition of fear memory. However, treatment with Ro256981 before FfB administration did not affect fear memory. FfB treatment reversed the learning impairment observed in the subgroup treated with Ro25-6981 alone. Analysis of the SR for the first three-trial block $\left(2^{\text {nd }}-4^{\text {th }}\right.$ trials) showed significant differences in mean SR for the saline, NMDA, Ro25-6981, andRo25-6981+FfB groups (0.15 mg. $\mathrm{Kg}^{-1} ; 0.30 \mathrm{mg} \cdot \mathrm{Kg}^{-1}$; or 0.65 mg. $\left.\mathrm{Kg}^{-1} \mathrm{FfB}\right)$ compared with the first trial $(P<0.0001)$. Furthermore, an ANOVA comparing the subsequent three-trial blocks (5-7 and 8-10) with the first three-trial block of the test 
revealed no differences $(P>0.05)$. The Ro25-6981 subgroup showed similar SR values across all trials of CS presentation (statistics shown in Table S6).

However, comparisons of the first trial of the extinction training test between the subgroups showed that the subgroups treated with Ro25-6981+FfB, at all doses, did not demonstrate differences in mean SR compared with the saline and NMDA subgroups $(P>0.05)$ or the Ro25-6981 alone subgroup, which showed no acquisition of conditioned fear (middle panel of Figure 4B). Analysis of the SR for the first three-trial block $\left(2^{\text {nd }}-4^{\text {th }}\right.$ trials) compared with the first trial showed no significant differences in the mean SR for the subgroups treated with saline, NMDA, Ro25-6981, or Ro25-6981+FfB $(P>0.05)$. Nevertheless, no significant difference in SR was found within the groups for the first three-trial block (2-4) compared with the subsequent three-trial blocks (5-7 and $8-10$; $P>0.05$; see also Table S6).

The subgroups treated with Ro25-6981+FfB, at all doses, exhibited higher mean SRs for the first trial than the saline subgroup on the extinction retention test $(P>0.05$; right panel of Figure 4B) and remained similar throughout the trials of the extinction training test. Comparisons between the first trial and the first three-trial block (2-4) showed reduced suppression of the licking response for all groups treated with Ro25-6981+FfB $(P<0.05)$. An ANOVA comparing the threetrial blocks demonstrated no significant differences in the mean SRs throughout the extinction retention session $(P>0.05$; Table S6).

A Two-way ANOVA comparison between groups treated with $\mathrm{FfB}$ vs. Ro $25-6981+\mathrm{FfB}$ revealed a significant groups $\times$ trial interaction $\left[F_{(55,495)}=2.094, P<0.0001\right]$ and main effects of trial $\left[F_{(11,99)}=31.20, P<0.0001\right]$ and groups $\left[F_{(5,45)}=2.873, P=0.0247\right)$. Analysis of the mean SR showed significant difference between Ro 25-6981 + $0.65 \mathrm{mg} . \mathrm{Kg}^{-1} \mathrm{FfB}$ vs. $0.65 \mathrm{mg} \cdot \mathrm{Kg}^{-1} \mathrm{FfB}$ to the first trial during extinction training $(P<0.0001)$. No significant difference was observed among subsequent three-trial blocks $(P>0.05)$. Furthermore, similar means SR were found to groups treated with Ro 25-6981+FfB to the first trial during extinction retention test. No significant difference was observed among subsequent three-trial blocks $(P>0.05)$.

In summary, our data show for the first time that treatment with Ro25-6981, an antagonist of the GluN2BNMDAR, impairs the acquisition of suppression of the licking response. Conversely, treatment with after FfB after Ro25-6981 administration, at all doses, reverses the learning impairment associated with the GluN2B-NMDAR antagonist. In this sense, GluN2B is involved in the acquisition of suppression of the licking response, but the disruptive effects of Ro25-6981 appear to be offset by treatment with FfB. Additionally, we showed that the spontaneous recovery observed in the $\mathrm{FfB}$ subgroups may be modulated by GluN2B because rats treated with Ro25-6981 before FfB administration seems to decrease the spontaneous recovery observed during the extinction training sessions compared with the rats treated with $\mathrm{FfB}$ alone (see Figure 2B).

\section{Ro25-6981 Treatment does not Prevent the Overexpression of Grin2a and Erk2 Caused by FfB, Although it Reduces Htr1a Expression}

We used treatment with Ro25-6981 prior to FfB to evaluate the roles of NMDARs, 5- $\mathrm{HT}_{1 \mathrm{~A}} \mathrm{R}_{S}, \mathrm{GABA}_{\mathrm{A}} \mathrm{R}_{S}$, and ERK2. Figure 4C shows the Htr1a, Grin2a, Grin2b, Gabra5, and Erk2 expression levels in the $\mathrm{DH}$ after the retention test $\left(8^{\text {th }}\right.$ day). Treatment with Ro25-6981 before FfB treatment, at all three doses, resulted in the overexpression of Grin2a $\left[F_{(5,12)}=107.1, P<0.0001\right]$ and $\operatorname{Erk} 2\left[F_{(5,12)}=90.89, P<0.0001\right]$ and the decreased expression of Htrla $\left[F_{(5,12)}=32.67, P<0.0001\right]$ and Gabra5 $\left[F_{(5,12)}=12.44, P=0.0002\right]$ compared with the control treatment. No change in Grin2b was observed after Ro25-6981 or Ro25-6981+FfB treatment $\left[F_{(5,12)}=20.18\right]$. A ANOVA analysis revealed that treatment with Ro25-6981 before $\mathrm{FfB}$, resulted in the overexpression of Grin $2 a\left[F_{(5,12)}=134.8, P<0.0001\right]$ and $\operatorname{Erk} 2\left[F_{(5,12)}=47.98, P<0.0001\right]$ and the decreased expression of Htrla $\left[F_{(5,12)}=361.7, P<0.0001\right]$ and Gabra5 $\left[F_{(5,12)}=\right.$ $32.57, P<0.0001]$ in relation to groups treated with FfB alone. Additionally, NMDA treatment resulted in the overexpression of Grin $2 b$ compared with all other treatments $(P<0.0001)$ and in the overexpression of Erk2 compared with saline or Ro25-6981 treatment $(P<0.001$; see Table S7).

Figure 4D shows that treatment with Ro25-6981+FfB increased the Grin2a $\left[F_{(5,12)}=14.47, P=0.0001\right]$, Erk2 $\left[F_{(5,12)}=44.78, P<0.0001\right], H \operatorname{Hrla}\left[F_{(5,12)}=158.6\right.$, $P<0.0001]$, and Grin $2 b\left[F_{(5,12)}=5.37, P=0.008\right]$ expression levels in the $\mathrm{DH}$ after the extinction retention test $\left(10^{\text {th }}\right.$ day) compared with saline treatment. No significant differences in Gabra5 expression were observed between the subgroups treated with Ro25-6981+FfB and the saline subgroup $\left[F_{(5,12)}=1.169, P=0.3790\right]$. Furthermore, comparison among groups treated with Ro25-6981 before FfB treatment resulted in the overexpression of Grin2a $\left[F_{(5,12)}=32.68, P<0.0001\right]$ and $\operatorname{Erk} 2\left[F_{(5,12)}=34.58, P<0.0001\right]$ and Htrla $\left[F_{(5,12)}=299.0\right.$, $P<0.0001]$. Further, significant difference tog Grin2b was seeing to groups treated with Ro25-6981 before $0.65 \mathrm{mg} \cdot \mathrm{Kg}^{-1}$ $\mathrm{FfB}$ in relation to $0.65 \mathrm{mg} \cdot \mathrm{Kg}^{-1} \mathrm{FfB}$ group $\left[F_{(5,12)}=4.727\right.$, $P=0.0128]$.

In summary, treatment with Ro25-6981 reduced the expression of Gabra5, Erk2, and Ht1ra in the DH after the retention test, although treatment with FfB reduced the effects of Ro25-6981 on Gabra5 and Htr1a expression and increased Grin2a and Erk2 expression. Conversely, treatment with Ro25$6981+\mathrm{FfB}$ increased Htr1a expression after the extinction retention test. Furthermore, treatment with FfB after Ro25-6981 administration increased the Htr1a, Grin2b, Grin2a, and Erk2 expression levels in the $\mathrm{DH}$ after the extinction retention test (see Table S7).

\section{Effects of FfB on Fear Memory After Blocking $\mathrm{GABA}_{\mathrm{A}} \mathrm{Rs}$}

The effects of specifically blocking $\mathrm{GABA}_{\mathrm{A}} \mathrm{Rs}$ prior to $\mathrm{FfB}$ treatment before conditioning on the results of the retention test, extinction training, and the extinction retention test are shown in Figure 5B. A Two-way ANOVA revealed a significant trial $\times$ 
group interaction $\left[F_{(55,648)}=2.695, P<0.0001\right]$, a main effect of group $\left[F_{(5,648)}=6.416, P<0.0001\right]$ and a main effect of trial $\left[F_{(11,648)}=11.77, P<0.0001\right]$.

Analysis of the mean SRs for the first trial of the retention test showed that treatment with picrotoxin, an antagonist of $\mathrm{GABA}_{\mathrm{A}} \mathrm{Rs}$, or picrotoxin+FfB did not prevent the acquisition of conditioned fear. These subgroups showed a similar mean SR to the saline subgroup $(P>0.05)$. Conversely, animals treated with diazepam exhibited reduced suppression of the licking response compared with the animals treated with saline, picrotoxin or picrotoxin $+\mathrm{FfB}(P<0.001)$.

Analysis of the SR for the first three-trial block $\left(2^{\text {nd }}-4^{\text {th }}\right.$ trials) compared with the first trial showed significant differences in the mean SR for the subgroups treated with saline, picrotoxin, or picrotoxin $+\mathrm{FfB}\left(0.15 \mathrm{mg} . \mathrm{Kg}^{-1}, 0.30 \mathrm{mg} . \mathrm{Kg}^{-1}\right.$, or $\left.0.65 \mathrm{mg} . \mathrm{Kg}^{-1} \mathrm{FfB} ; P<0.0001\right)$. An ANOVA comparing the first three-trial block (2-4) of extinction with the other three-trial blocks (5-7 and 8-10) demonstrated no significant differences in the mean SR between the subgroups ( $P>0.05$; see Table S8).

The data from the extinction training session are shown in the middle panel of Figure 5B. Comparisons between the groups showed that the subgroups treated with picrotoxin $+\mathrm{FfB}$, at all doses, demonstrated differences in mean SRs in the first trial compared to the saline, picrotoxin and diazepam subgroups $(P<$ $0.0001)$. In addition, rats treated with picrotoxin+FfB showed spontaneous recovery similar to that observed in rats treated with $\mathrm{FfB}$ alone (see Figure 2B). Furthermore, no differences in SR on the first trial were observed between the saline and picrotoxin subgroups $(P>0.05)$. Analysis of the mean SR during the first three-trial block (2-4) showed that rats treated with picrotoxin $+\mathrm{FfB}$ at all doses demonstrated reduced suppression of the licking response compared with the mean SR for the first trial $(P<0.0001)$. The saline and picrotoxin subgroups exhibited a similar mean SR across successive exposures to the CS during extinction training. Similar mean SRs were observed for all groups across the subsequent three-trial blocks (5-7 and 8-10; $P>0.05$; see Table S8).

Similar to the previous sessions, on the extinction retention test, rats treated with picrotoxin $+\mathrm{FfB}$, at all doses, showed spontaneous recovery on the first trial, as demonstrated by the higher SR means in the picrotoxin + FfB subgroups $(P>0.001$; Figure 5B, right panel). A reduced mean $S R$ was observed in the picrotoxin $+\mathrm{FfB}$ subgroups on the first three-trial block compared to the first trial $(P<0.0001)$. No significant difference in the SR was found within the groups for the first three-trial block (2-4) compared with the subsequent three-trial blocks (5-7 and 8-10; $P>0.05$; see also Table S8).

A Two-way ANOVA comparison between groups treated with FfB vs. Picrotoxin $+F f B$ revealed a significant groups $\times$ trial interaction $\left[F_{(55,495)}=1.091, P=0.3116\right]$ and main effects of trial $\left[F_{(11,99)}=45.11, P<0.0001\right]$ and groups $\left[F_{(5,45)}=5.375\right.$, $P=0.0006]$. Analysis of the mean SR showed no significant difference between groups treated with $\mathrm{FfB}$ vs. Picrotoxin+FfB, at all doses, to the first trial during retention test $(P>0.05)$, extinction training $(P>0.05)$ and extinction test sessions $(P>0.05)$. Significantly difference were observed among groups treated with $\mathrm{FfB}$, at a dose $0.15 \mathrm{mg} . \mathrm{Kg}^{-1}$ and $0.65 \mathrm{mg} \cdot \mathrm{Kg}^{-1} \mathrm{FfB}$ $(P<0.05)$. Furthermore, analysis of SR means for the first trial showed significant difference among rats treated with different doses of FfB groups during extinction training and extinction retention test $(P<0.001)$. No significant difference was observed among subsequent three-trial blocks $(P>0.05)$.

In summary, our data demonstrated that each group treated with picrotoxin prior to $\mathrm{FfB}$ administration acquired fear memory. Conversely, diazepam treatment impaired the acquisition of fear memory. Furthermore, we showed that treatment with picrotoxin $+\mathrm{FfB}$ resulted in spontaneous recovery in the first trial of extinction training and the extinction retention test, although the suppression gradually decreased over the trials. Therefore, rats treated with FfB showed within-session extinction of fear memory. These data suggest that spontaneous recovery is not modulated by $\mathrm{GABA}_{\mathrm{A}}$ Rs.

\section{Picrotoxin Prevents the Overexpression of Gabra5 and Grin2a Caused by FfB}

Treatment with picrotoxin prior to FfB treatment, at a dose of 0.15 or $0.65 \mathrm{mg} . \mathrm{Kg}^{-1} \mathrm{FfB}$, did not prevent the increase in the expression of Htrla $\left[F_{(5,12)}=28.02, P<0.0001\right]$ or Erk2 $\left[F_{(5,12)}=84.48, P<0.0001\right]$ in the $\mathrm{DH}$ after the retention test compared with saline, picrotoxin, or diazepam treatment (Figure 5C), as observed in the subgroups treated with FfB alone (Figure 2C). A ANOVA analysis revealed that treatment with picrotoxin before $\mathrm{FfB}$, resulted in the downexpression of Htrla $\left[F_{(5,12)}=128.7 P<0.0001\right]$, Grin $2 b\left[F_{(5,12)}=15.22, P<\right.$ $0.0001]$ and $\operatorname{Erk} 2\left[F_{(5,12)}=22.81, P<0.0001\right]$, at all doses, and Gabra5 $\left[F_{(5,12)}=28.02, P<0.0001\right]$ and $\operatorname{Grin} 2 a\left[F_{(5,12)}=8515\right.$, $P<0.00002]$, at a higher doses in relation to groups treated with $\mathrm{FfB}$ alone. Additionally, picrotoxin $+\mathrm{FfB}$ treatment did reduce Grin $2 b$ expression $\left[F_{(5,12)}=14.42, P<0.0001\right]$, but no change was observed in the expression of $\operatorname{Grin} 2 a\left[F_{(5,12)}=12.24, P=\right.$ $0.0001]$ or Gabra5 $\left[F_{(5,12)}=7.580, P=0.0020\right]$. Furthermore, picrotoxin increased Gabra5, and Erk2 expression in the $\mathrm{DH}$ $(P<0.0001)$. Conversely, diazepam treatment decreased Htrla, Grin2a, Erk2, and Grin2b expression in the DH (see Table S9).

The data shown in Figure 5D demonstrate the upregulation of Erk2 $\left[F_{(5,12)}=90.76, P<0.0001\right]$ and Grin2a $\left[F_{(5,12)}=\right.$ 67.51] expression in the $\mathrm{DH}$ after the extinction retention session for the subgroups treated with picrotoxin $+F \mathrm{fB}$ compared to those treated with saline, picrotoxin or diazepam $(P>0.0001)$. Upregulated Htr1a $\left[F_{(5,12)}=23.98, P<0.0001\right]$ and Erk2 $\left[F_{(5,12)}=26.24, P<0.0001\right]$ expression was observed in the picrotoxin $+\mathrm{FfB}$ in relation to FfB group. Similarly, upregulated Htrla $\left[F_{(5,12)}=10.75\right]$ expression was observed in the picrotoxin $+\mathrm{FfB}$ compared with the saline and diazepam subgroups $(P<0.0001)$. Moreover, we showed that picrotoxin resulted in the overexpression of $H \operatorname{tr} 1 a, G \operatorname{Gin} 2 b\left[F_{(5,12)}=31.61\right.$, $P<0.0001]$, and Gabra5 $\left[F_{(5,12)}=12.13, P=0.0020\right]$ compared with saline. Downregulated $\operatorname{Grin} 2 b\left[F_{(5,12)}=22.08\right.$, $P<0.0001]$, Grin2a $\left[F_{(5,12)}=22.04, P<0.0001\right]$ and Gabra5 $\left[F_{(5,12)}=14.46, P<0.0001\right]$ expression was observed in the picrotoxin $+\mathrm{FfB}$ in relation to $\mathrm{FfB}$ group. Furthermore, diazepam increased Htrla expression and decreased Grin2a and Gabra5 expression $(P<0.0001$; see Table S9).

In summary, treatment with picrotoxin before FfB administration, at all doses, increased Htrla and Erk2 expression in the DH after the acquisition and extinction of fear memory 
and reduced Grin2b expression and prevented the increase in Grin2a and Gabra5 expression after the retention test. Furthermore, this treatment decreased Grin $2 b$ and Gabra5 expression after the extinction retention test.

\section{DISCUSSION}

The major findings of our study are as follows. (i) Rats treated with FfB acquired suppression of the licking response, and FfB upregulated the expression of Htr1a, Grin2a, Gabra5, and Erk2 in the $\mathrm{DH}$ after the acquisition of conditioned fear, compared to rats exposed to the CS alone, naïve rats and Sintocalmy ${ }^{\circledR}$-treated rats. (ii) Rats treated with $\mathrm{FfB}$, at all doses, showed spontaneous recovery when subjected to the extinction training and extinction retention test sessions; these observations were correlated with Htr1a and Erk2 overexpression in the DH. (iii) These findings were confirmed by data from treatment with (S)-WAY100135, which reduced the lick SR and inhibit spontaneous recovery. Further, data from DH samples obtained from rats treated with (S)-WAY100135 prior to FfB resulted in the downregulation of Htr1a expression and no modulation of Erk2 expression after the retention test and the extinction retention test. (iv) Our data are in line with previous findings concerning the requirement of GluN2B for fear memory formation (Sotres-Bayon et al., 2007, 2009). In particular, we present evidence that treatment with Ro25-6981 disrupts the acquisition of suppression of the licking response. Nevertheless, treatment with FfB after Ro256981 reversed the dose-dependent deficit in the acquisition of fear memory caused by Ro25-6981, which was associated with upregulation of Grin2a and Erk2 expression and downregulation of Htrla and Gabra5 expression in the DH after the retention test. The occurrence of spontaneous recovery to group treated with Ro25-6981 before FfB during extinction retention test seems to be associated with increase of Grin2b, Grin2a, and Erk2 expression. (v) Treatment with picrotoxin prior to FfB administration no inhibits the spontaneous recovery of fear. This observation was correlated with overexpression of Htrla and Erk2 and no modulation of Gabra5 expression in the DH. This result suggested that spontaneous fear recovery is not modulated by inactivation of $\mathrm{GABA}_{\mathrm{A}} \mathrm{Rs}$; however, the data concerning Gabra5 expression in the $\mathrm{DH}$ indicated that $\mathrm{FfB}$ modulated the expression of the $\alpha 5$-subunit, which is particularly important for mediating the process of memory formation in the hippocampus (Bannerman et al., 2004; Rudolph and Möhler, 2006; Atack, 2011). Additionally, treatment with diazepam and Sintocalmy ${ }^{\circledR}$ disrupt the acquisition of fear memory, in which was associated with downregulation of Grin2a expression in the DH. Several pharmacological studies have indicated that the administration of diazepam before training impairs LTM, as evaluated in a behavioral model such as IA (Izquierdo and Ferreira, 1989), contextual fear conditioning (Harris and Westbrook, 1998), or conditioned suppression (Oliveira et al., 2009). Consistent with this evidence, our results show that acute treatment with $4.0 \mathrm{mg} \cdot \mathrm{Kg}^{-1}$ diazepam impaired fear memory acquisition and highlight the role of $\mathrm{GABA}_{\mathrm{A}} \mathrm{R}$ in this process. Together with previous data, our current data further support the concept that flavonoid fractions do not prevent fear memory extinction within a session (de Oliveira et al., 2014). In addition, these data suggest an important role of the $\mathrm{DH}$ in mediating the acquisition and extinction of conditioned suppression of the lick response.

The roles of the hippocampus in the acquisition, consolidation, and retrieval of fear memory (Kim and Fanselow, 1992; Cammarota et al., 2008) and in fear extinction have been extensively studied in different rodent paradigms (Izquierdo, 1997; Ji and Maren, 2008). Further, the involvement of a circuit including the hippocampus, the pre-frontal cortex and the amygdala in these processes has long been established (Vinogradova, 2001; Fanselow and Dong, 2010). However, the present data suggest an important role of the hippocampus in conditioned suppression, whereas hippocampal plasticity may represent another function of the hippocampus in addition to contextual fear memory modulation and executive and integrative functions (McNaughton and Gray, 2000; Anagnostaras et al., 2001; Vinogradova, 2001; Sanders et al., 2003). Further, many theories have attempted to explain both the neurochemical processes that occur during the acquisition and extinction of fear memory and in the mechanism by which new drug, which are designed to enhance the consolidation or facilitate the extinction of fear memories, might modulate these neurochemical systems (Ji and Maren, 2007; Dalton et al., 2008). However, much less is known about drugs that modulate the brain substrates of extinction, conditioned inhibition, and other inhibitory processes involved in the suppression of a motivated response or the basis of spontaneous recovery. In addition, very few studies have shown the effects of drug treatment prior to conditioning training on fear extinction or spontaneous recovery, i.e., the relationship between the strength of fear memory acquisition and spontaneous recovery. In contrast, the majority of the existing data show the effects of pre-extinction treatment on spontaneous recovery.

Our data suggest that the role of the hippocampus in the acquisition and extinction of lick suppression is dependent on the interaction between glutamatergic, serotoninergic and GABAergic neurotransmission via the activation or inactivation of specific NMDARs, GABA ${ }_{A}$ Rs, and $5-\mathrm{HT}_{1 \mathrm{~A}} \mathrm{Rs}$, as demonstrated by the results from pharmacological manipulation and differential gene expression of Grin2a, Grin2b, Gabra5, Htr1a, and Erk2. The reappearance of a conditioned response after acquisition and training for extinction of fear memory, as shown in our subgroups treated with FfB, has been previously described (Bouton, 1993; Rescorla, 2004; Leung and Westbrook, 2008; Quirk and Mueller, 2008). Specifically, it is thought that the persistence of a fear response after extinction training is associated with anxietyrelated disorders (Davis et al., 2006). However, we showed that $\mathrm{FfB}$ enabled the acquisition of extinction within a session despite the occurrence of spontaneous recovery. Although these findings may seem paradoxical, our current findings raise the hypothesis that the original memory was somewhat enhanced, i.e., better preserved; therefore, the flavones from Erythrina falcata may be studied as a novel pharmacotherapy for the treatment of cognitive impairment. Furthermore, we believe that the reappearance of the original memory (spontaneous recovery) observed after FfB treatment is associated with the expression of Htrla, Erk2, and Grin2a in the DH. 


\section{$5 \mathrm{HT}_{1 \mathrm{~A}} \mathrm{Rs}$ as a Potential Target for the Effects of FfB on Spontaneous Recovery}

Drugs that modulate the serotoninergic system are important for cognitive and emotional functions, and $5-\mathrm{HT}_{1 \mathrm{~A}} \mathrm{Rs}$ are involved in this process. The heteromeric $5-\mathrm{HT}_{1 \mathrm{~A}} \mathrm{R}$ is highly expressed in the hippocampus (Barnes and Sharp, 1999), where it modulates GABA- and glutamate-mediated activities (Jacobs and Azmitia, 1992; Barnes and Sharp, 1999; Meneses and Perez-Garcia, 2007). Activation of post-synaptic $5-\mathrm{HT}_{1 \mathrm{~A}} \mathrm{Rs}$ (heteroreceptors) in the hippocampus is a central component of conflict resolution and anti-anxiety effects. Alternatively, reduced $5-\mathrm{HT}_{1 \mathrm{~A}} \mathrm{R}$ expression results in a deficit in hippocampal-dependent memory (Bert et al., 2005, 2006; Altieri et al., 2013). However, the effect of the activation of $5-\mathrm{HT}_{1 \mathrm{~A}} \mathrm{R}$ on the modulation of Erk2 expression remains controversial and may depend on neuronal origin and maturation states. Treatment with a $5-\mathrm{HT}_{1 \mathrm{~A}} \mathrm{R}$ agonist increased ERK phosphorylation and activity in the hippocampal neuronderived cell line HN2-5 and in hippocampal slices cultured from postnatal day-15 animals (Adayev et al., 1999). In addition to these effects, the activation of $5-\mathrm{HT}_{1 \mathrm{~A}} \mathrm{Rs}$ alters the dynamics of other neurotransmission systems.

The serotonergic regulation of NMDAR function in the DH was described in pyramidal neurons in the prefrontal cortex (Yuen et al., 2005). Additionally, the activation of $5-\mathrm{HT}_{1 \mathrm{~A}} \mathrm{Rs}$ resulted in disruption of the transport of GluN2B subunitcontaining vesicles in dendrites, and this transport is regulated by the CaMKII and ERK signaling pathways (Yuen et al., 2005). However, further investigations of the adaptive changes in receptor functions and their specific localization are needed to elucidate the precise role of flavonoids.

Intra-hippocampal treatment with (S)-WAY100135 alone did not affect the punished response in rats (Przegalinski et al., 1995). Therefore, our data suggest that treatment with (S)WAY100135 reduced lick suppression and that treatment with FfB was unable to reverse this effect. Moreover, the treatment with (S)-WAY100135 modulated Grin2a and Grin2b expression. In this sense, heteromeric $5-\mathrm{HT}_{1 \mathrm{~A}} \mathrm{Rs}$ in the $\mathrm{DH}$ appear to be related to the acquisition of conditioned fear in addition to anti-conflict functions because rats treated with (S)-WAY100135 before FfB administration did not show spontaneous recovery.

The reduced Grin2a, Grin2b, and Htr1a expression in the DH in groups treated with (S)-WAY100135 or (S)$\mathrm{WAY}+\mathrm{FfB}$ may underlie the reduced lick suppression and lack of spontaneous recovery. This result suggests an interaction between neurochemical systems. Therefore, the $5-\mathrm{HT}_{1 \mathrm{~A}} \mathrm{R}$ represents an additional potential target for the regulation of emotion and cognition in the $\mathrm{DH}$.

\section{Activation of the GluN2B-NMDARs is Required for Acquisition of Conditioned Suppression and Their Inactivation Before FfB Treatments Modulates the Spontaneous Recovery}

Since the discovery of the involvement of NMDARs in longterm potentiation (LTP) at CA1 synapses in the hippocampus, it has become evident that NMDARs are critical for a variety of cognitive processes, such as the acquisition and extinction of fear conditioning (Morris et al., 1986; Bliss and Collingridge, 1993). GluN2A and GluN2B are the predominant subunits of NMDARs. Furthermore, both of these subunits are expressed in the adult brain, predominantly in forebrain regions such as the amygdala, the prefrontal cortex, and the hippocampus, which are involved in the signaling pathways required for aversive memory formation (Schenberg et al., 2006; Mathur et al., 2009; Sotres-Bayon et al., 2009; Morris, 2013).

The hippocampal functions of NMDARs, particularly the GluN2B and GluN2A subunits, in fear memory have been reported (Zhang et al., 2008; Brigman et al., 2010). Several works have suggested that the NMDAR subunit composition could be responsible for the induction of the two forms of plasticity: LTP and long-term depression (LTD) (Shipton and Paulsen, 2014). The contribution of each subunit to ERK2 activation appears to be related to the localization and population of these receptors as well as the behavioral paradigm evaluated (Traynelis et al., 2010). NMDARs either produce weak ERK2 activation or do not activate ERK2 (Gao et al., 2010). Myung et al. (2005) showed that the GluN2B-NMDAR is coupled to the inhibition, rather than the activation, of ERK1/2. Furthermore, differences between behavioral data and gene expression data may explain the different effects of the GluN2B-NMDAR on downstream pathways according to regional localization. Our data showed that Ro25-6981 downregulated the expression of Erk2 in the DH, which resulted in the impairment of conditioned suppression. Alternatively, pharmacological activation of NMDARs increased Grin $2 b$ and Erk2 expression but did not affect Grin $2 a$ expression in the $\mathrm{DH}$ after the acquisition of conditioned suppression. Furthermore, treatment with FfB after Ro25-6951 administration increased Grin $2 a$ and Erk2 expression in the DH. Thus, Erk2 activity is closely related to the acquisition of conditioned suppression, as well as extinction and spontaneous recovery.

The increase in Erk2 expression, in response to the acquisition of fear memory or to NMDAR stimulation, has been consistently related to memory-dependent plasticity in the hippocampus (Atkins et al., 1998; Cammarota et al., 2000). The first evidence for the involvement of MAPK in LTP and fear memory originated from studies by English and Sweatt (1996) and Atkins et al. (1998), which showed that ERK2 is required for the formation of LTM in a fear conditioning paradigm in the hippocampus. The levels of ERK2 are elevated following the activation of NMDARs and during the influx of calcium (Impey et al., 1999) but are decreased by $5-\mathrm{HT}_{1 \mathrm{~A}}$-receptor activation or infusion of an agonist of the serotonergic $5-\mathrm{HT}_{1 \mathrm{~A}} \mathrm{R}$ in the hippocampus as Erk1/2 plays an important role in neuroprotection and synaptic activity.

In addition to hippocampal NMDARs and $5-\mathrm{HT}_{1 \mathrm{~A}} \mathrm{Rs}$, $\mathrm{GABA}_{\mathrm{A}}$ Rs play an important role in synaptic plasticity and therefore contribute to the acquisition of fear memory. Accordingly, drugs that modulate GABAergic transmission have been shown to interfere with fear acquisition and extinction (Chhatwal et al., 2005; Delamater et al., 2009; Oliveira et al., 2009). 


\section{Activation of $\mathrm{GABA}_{\mathrm{A}}$ Rs Impairs Acquisition of Conditioned Suppression. Their Inactivation, Before FfB Treatment, However, didn't Prevent the Spontaneous Recovery}

We observed that conditioned suppression was impaired in the subgroups treated with Sintocalmy ${ }^{\circledR}$ or diazepam, and this impairment appeared to be related to the downregulation of Grin $2 a$ expression in the DH. The pharmacological properties and behavioral actions of benzodiazepines, such as amnesic, sedative, and antianxiety effects, on $\mathrm{GABA}_{\mathrm{A}} \mathrm{Rs}$ appear to be mediated by the $\alpha 1$ subunit, which is preferentially located in interneurons of forebrain areas (Collinson et al., 2002). However, evidence has demonstrated that the $\mathrm{GABA}_{\mathrm{A}} \mathrm{R} \alpha 5$ subunit is highest in the hippocampus compared with deep cortical layers and the amygdala (Rudolph and Möhler, 2014), where it mediates memory formation (Yee et al., 2004; Rudolph and Möhler, 2006; Atack, 2011) and is involved in learning and memory tasks (Harris and Westbrook, 1998; Collinson et al., 2002, 2006). Although Gabra5 expression was not modulated in rats subjected to fear conditioning with or without FfB treatment or to the acquisition of conditioned suppression following FfB treatment, rats treated with picrotoxin displayed upregulation of Gabra5 expression and showed acquisition of memory. In addition to the role of the $\alpha 5$ subunit in the acquisition of fear memory, its modulation in the $\mathrm{DH}$ after extinction of fear memory is supported by data from the subgroups treated with picrotoxin+FfB; these data suggest that the $\alpha 5$ subunit is not correlated with spontaneous recovery. Thus, our data reveal a central role of the $\alpha 5$ subunit of the $\mathrm{GABA}_{\mathrm{A}} \mathrm{R}$ in the acquisition of conditioned emotional suppression, as evaluated by the lick response. The memory-enhancing effects of benzodiazepine site partial inverse agonists have been shown (Yee et al., 2004).

\section{CONCLUSION}

The major fear memory/treatment-dependent changes observed in our study included the spontaneous recovery of fear memory, which may be related to the enhancement of consolidation of fear memory. No anti-anxiety effects were observed after treatment with FfB. Furthermore, for the first time, we showed that the spontaneous recovery of fear memory may be correlated with the combined activation of GluN2A-containing NMDARs, and $5-\mathrm{HT}_{1 \mathrm{~A}} \mathrm{Rs}$ in the $\mathrm{DH}$, which, in turn, modulates ERK1/2 activity. Finally, the results from gene expression analysis in the $\mathrm{DH}$ and the results showing the modulatory effects of FfB treatment indicate that the $\mathrm{DH}$ appears to anatomically and functionally subserve other structures involved in the acquisition and extinction of fear memory formation, such as the amygdala and the prefrontal cortex. Together, our data provide important information concerning the molecular basis of fear-conditioned suppression and the role of the $\mathrm{DH}$ in these processes, and our results suggest that $\mathrm{FfB}$ may represent a potential therapeutic target for preventing or treating neurocognitive impairments.

\section{ACKNOWLEDGMENTS}

This work is dedicated to Dra Elenice Aparecida de Moraes Ferrari (in memoriam). This study was supported by the São Paulo State Research Foundation (FAPESP) (grant 2009/15229-3 and 2013/20378-8 to SC). DO and CZ are scholars from CAPES. JC is an investigator on the Brazilian Research Council (CNPq).

\section{SUPPLEMENTARY MATERIAL}

The Supplementary Material for this article can be found online at: http://journal.frontiersin.org/article/10.3389/fnbeh. 2015.00345

Figure S1 | HPLC-DAD-ESI/MS ${ }^{n}$ analysis of the flavonoidic fraction (FfB) from the roots of Erythrina falcata using a C18 Luna column (A,B). TIC was performed in negative mode, and $\mathrm{MS}^{2}$ spectra of deprotonated molecules (A) were obtained as follows: (1) vicenin-2 $[\mathrm{M}-\mathrm{H}]^{-}$at $\mathrm{m} / \mathrm{z} 593$, (2) vicenin- $1[\mathrm{M}-\mathrm{H}]^{-}$at $\mathrm{m} / \mathrm{z} 563$, (3) vitexin $[\mathrm{M}-\mathrm{H}]^{-}$at $\mathrm{m} / \mathrm{z} 431$, (4) isovitexin $[\mathrm{M}-\mathrm{H}]^{-}$at $\mathrm{m} / \mathrm{z} 431$, (5) 6-C-glycoside diosmetin $[\mathrm{M}-\mathrm{H}]^{-}$at $\mathrm{m} / \mathrm{z} 461$, and (6) apigenin $[\mathrm{M}-\mathrm{H}]^{-}$at $\mathrm{m} / \mathrm{z} 269$. The chromatogram was recorded at $254 \mathrm{~nm}$ for the UV spectra of compounds 1-6 (A).

\section{REFERENCES}

Adayev, T., El-Sherif, Y., Barua, M., Penington, N. J., and Banerjee, P. (1999). Agonist stimulation of the serotonin(1A) receptor causes suppression of anoxia-induced apoptosis via mitogen-activated protein kinase in neuronal HN2-5 cells. J. Neurochem. 72, 1489-1496. doi: 10.1046/j.1471-4159.1999.721489.x

Aguilar, E., Tena-Sempere, M., Aguilar, R., González, D., and Pinilla, L. (1997). Interactions between N-methyl-D-aspartate, nitric oxide and serotonin in the control of prolactin secretion in prepubertal male rats. Eur. J. Endocrinol. 137, 99-106. doi: 10.1530/eje.0.1370099

Alonso, M., Viola, H., Izquierdo, I., and Medina, J. H. (2002). Aversive experiences are associated with a rapid and transient activation of ERKs in the rat hippocampus. Neurobiol. Learn. Mem. 77, 119-124. doi: 10.1006/nlme.2000.4000

Altieri, S. C., Garcia-Garcia, A. L., Leonardo, E. D., and Andrews, A. M. (2013). Rethinking 5-HT1A receptors: emerging modes of inhibitory feedback of

relevance to emotion-related behavior. ACS Chem. Neurosci. 4, 72-83. doi: $10.1021 / \mathrm{cn} 3002174$

Anagnostaras, S. G., Gale, G. D., and Fanselow, M. S. (2001). Hippocampus and contextual fear conditioning: recent controversies and advances. Hippocampus 11, 8-17. doi: 10.1002/1098-1063(2001)11:1<8::AID-HIPO1015>3.0. $\mathrm{CO} ; 2-7$

Apergis-Schoute, A. M., Debiec, J., Doyère, V., LeDoux, J. E., and Schafe, G. E. (2005). Auditory fear conditioning and long-term potentiation in the lateral amygdala require ERK/MAP kinase signaling in the auditory thalamus: a role for presynaptic plasticity in the fear system. J. Neurosci. 25, 5730-5739. doi: 10.1523/JNEUROSCI.0096-05.2005

Atack, J. R. (2011). GABAA receptor subtype-selective modulators. II. $\alpha 5$-selective inverse agonists for cognition enhancement. Curr. Top. Med. Chem. 11, 1203-1214. doi: 10.2174/156802611795371314

Atkins, C. M., Selcher, J. C., Petraitis, J. J., Trzaskos, J. M., and Sweatt, J. D. (1998). The MAPK cascade is required for mammalian associative learning. Nat. Neurosci. 1, 602-609. doi: 10.1038/2836 
Ballesteros, C. I., de Oliveira Galvão, B., Maisonette, S., and Landeira-Fernandez, J. (2014). Effect of dorsal and ventral hippocampal lesions on contextual fear conditioning and unconditioned defensive behavior induced by electrical stimulation of the dorsal periaqueductal gray. PLOS ONE 9:e83342. doi: 10.1371/journal.pone.0083342

Bannerman, D. M., Rawlins, J. N., McHugh, S. B., Deacon, R. M., Yee, B. K., Bast, T., et al. (2004). Regional dissociations within the hippocampusmemory and anxiety. Neurosci. Biobehav. Rev. 28, 273-283. doi: 10.1016/j.neubiorev.2004.03.004

Barnes, N. M., and Sharp, T. (1999). A review of central 5-HT receptors and their function. Neuropharmacology 38, 1083-1152. doi: 10.1016/S00283908(99)00010-6

Beck, C. H., and Fibiger, H. C. (1995). Conditioned fear-induced changes in behavior and in the expression of the immediate early gene c-fos: with and without diazepam pretreatment. J. Neurosci. 15, 709-720.

Bert, B., Dere, E., Wilhelmi, N., Kusserow, H., Theuring, F., Huston, J. P., et al. (2005). Transient overexpression of the 5-HT1A receptor impairs water-maze but not hole-board performance. Neurobiol. Learn. Mem. 84, 57-68. doi: 10.1016/j.nlm.2005.03.005

Bert, B., Fink, H., Hörtnagl, H., Veh, R. W., Davies, B., Theuring, F., et al. (2006). Mice over-expressing the 5-HT1A receptor in cortex and dentate gyrus display exaggerated locomotor and hypothermic response to 8-OH-DPAT. Behav. Brain Res. 167, 328-341. doi: 10.1016/j.bbr.2005.09.020

Blanchard, R. J., and Blanchard, D. C. (1969). Passive and active reactions to feareliciting stimuli. J. Comp. Physiol. Psychol. 68, 129-135. doi: 10.1037/h0027676

Bliss, T. V., and Collingridge, G. L. (1993). A synaptic model of memory: long-term potentiation in the hippocampus. Nature 361, 31-39. doi: 10.1038/361031a0

Bolles, R. C., and Collier, A. C. (1976). The effect of predictive cues on freezing in rats. Anim. Learn. Behav. 4, 6-8. doi: 10.3758/BF03211975

Bouton, M. E. (1993). Context, time, and memory retrieval in the interference paradigms of Pavlovian learning. Psychol. Bull. 114, 80-99. doi: 10.1037/00332909.114.1.80

Brigman, J. L., Wright, T., Talani, G., Prasad-Mulcare, S., Jinde, S., Seabold, G. K., et al. (2010). Loss of GluN2B-containing NMDA receptors in CA1 hippocampus and cortex impairs long-term depression, reduces dendritic spine density, and disrupts learning. J. Neurosci. 30, 4590-4600. doi: 10.1523/JNEUROSCI.0640-10.2010

Cammarota, M., Bevilaqua, L. R., Ardenghi, P., Paratcha, G., Levi de Stein, M., Izquierdo, I., et al. (2000). Learning-associated activation of nuclear MAPK, CREB and Elk-1, along with Fos production, in the rat hippocampus after a one-trial avoidance learning: abolition by NMDA receptor blockade. Brain Res. Mol. Brain Res. 76, 36-46. doi: 10.1016/S0169-328X(99) 00329-0

Cammarota, M., Bevilaqua, L. R., Rossato, J. I., Lima, R. H., Medina, J. H., and Izquierdo, I. (2008). Parallel memory processing by the CA1 region of the dorsal hippocampus and the basolateral amygdala. Proc. Natl. Acad. Sci. U.S.A. 105, 10279-10284. doi: 10.1073/pnas.0805284105

Cerutti, J. M., Delcelo, R., Amadei, M. J., Nakabashi, C., Maciel, R. M., Peterson, B., et al. (2004). A preoperative diagnostic test that distinguishes benign from malignant thyroid carcinoma based on gene expression. J. Clin. Invest. 113, 1234-1242. doi: 10.1172/JCI19617

Chhatwal, J. P., Myers, K. M., Ressler, K. J., and Davis, M. (2005). Regulation of gephyrin and GABAA receptor binding within the amygdala after fear acquisition and extinction. J. Neurosci. 25, 502-506. doi: 10.1523/JNEUROSCI.3301-04.2005

Collinson, N., Atack, J. R., Laughton, P., Dawson, G. R., and Stephens, D. N. (2006). An inverse agonist selective for alpha5 subunit-containing GABA A receptors improves encoding and recall but not consolidation in the Morris water maze. Psychopharmacology (Berl.) 188, 619-628. doi: 10.1007/s00213-0060361-z

Collinson, N., Kuenzi, F. M., Jarolimek, W., Maubach, K. A., Cothliff, R., Sur, C., et al. (2002). Enhanced learning and memory and altered GABAergic synaptic transmission in mice lacking the alpha 5 subunit of the GABAA receptor. J. Neurosci. 22, 5572-5580.

Coop, C. F., McNaughton, N., and Lambie, I. (1991). Effects of GABAA and GABAB receptor agonists on reticular-elicited hippocampal rhythmical slow activity. Eur. J. Pharmacol. 192, 103-108. doi: 10.1016/0014-2999(91)90075-2
Dalton, G. L., Wang, Y. T., Floresco, S. B., and Phillips, A. G. (2008). Disruption of AMPA receptor endocytosis impairs the extinction, but not acquisition of learned fear. Neuropsychopharmacology 33, 2416-2426. doi: 10.1038/sj.npp.1301642

Davis, M. (1990). Animal models of anxiety based on classical conditioning: the conditioned emotional response (CER) and the fear-potentiated startle effect. Pharmacol. Ther. 47, 147-165. doi: 10.1016/0163-7258(90)90084-F

Davis, M. (2006). Neural systems involved in fear and anxiety measured with fearpotentiated startle. Am. Psychol. 61, 741-756. doi: 10.1037/0003-066X.61.8.741

Davis, M., and Myers, K. M. (2002). The role of glutamate and gammaaminobutyric acid in fear extinction: clinical implications for exposure therapy. Biol. Psychiatry 52, 998-1007. doi: 10.1016/S0006-3223(02)01507-X

Davis, M., Myers, K. M., Chhatwal, J., and Ressler, K. J. (2006). Pharmacological treatments that facilitate extinction of fear: relevance to psychotherapy. NeuroRx 3, 82-96. doi: 10.1016/j.nurx.2005.12.008

de Oliveira, D. R., Zamberlam, C. R., Gaiardo, R. B., Rêgo, G. M., Cerutti, J. M., Cavalheiro, A. J., et al. (2014). Flavones from Erythrina falcata are modulators of fear memory. BMC Complement. Altern. Med. 14:288. doi: 10.1186/14726882-14-288

Decker, M. W., Tran, T., and McGaugh, J. L. (1990). A comparison of the effects of scopolamine and diazepam on acquisition and retention of inhibitory avoidance in mice. Psychopharmacology (Berl.) 100, 515-521. doi: 10.1007/BF02244005

Delamater, A. R., Campese, V., and Westbrook, R. F. (2009). Renewal and spontaneous recovery, but not latent inhibition, are mediated by gammaaminobutyric acid in appetitive conditioning. J. Exp. Psychol. Anim. Behav. Process. 35, 224-237. doi: 10.1037/a0013293

English, J. D., and Sweatt, J. D. (1996). Activation of p42 mitogen-activated protein kinase in hippocampal long term potentiation. J. Biol. Chem. 271, 24329-24332. doi: $10.1074 /$ jbc. 271.40 .24329

Erlich, J. C., Bush, D. E. A., and Ledoux, J. E. (2012). The role of the lateral amygdala in the retrieval and maintenance of fear-memories formed by repeated probabilistic reinforcement. Front. Behav. Neurosci. 6:16. doi: 10.3389/fnbeh.2012.00016

Fanselow, M. S. (1980). Conditioned and unconditional components of post-shock freezing. Pavlov. J. Biol. Sci. 15, 177-182.

Fanselow, M. S., and Dong, H. W. (2010). Are the dorsal and ventral hippocampus functionally distinct structures? Neuron 65, 7-19. doi: 10.1016/j.neuron.2009.11.031

Fanselow, M. S., and Helmstetter, F. J. (1988). Conditional analgesia, defensive freezing, and benzodiazepines. Behav. Neurosci. 102, 233-243. doi: 10.1037/0735-7044.102.2.233

Fendt, M., and Fanselow, M. S. (1999). The neuroanatomical and neurochemical basis of conditioned fear. Neurosci. Biobehav. Rev. 23, 743-760. doi: 10.1016/S0149-7634(99)00016-0

Furini, C., Myskiw, J., and Izquierdo, I. (2014). The learning of fear extinction. Neurosci. Biobehav. Rev. 47, 670-683. doi: 10.1016/j.neubiorev.2014.10.016

Gamet-Payrastre, L., Manenti, S., Gratacap, M. P., Tulliez, J., Chap, H., and Payrastre, B. (1999). Flavonoids and the inhibition of PKC and PI 3-kinase. Gen. Pharmacol. 32, 279-286. doi: 10.1016/S0306-3623(98) 00220-1

Gao, C., Gill, M. B., Tronson, N. C., Guedea, A. L., Guzmán, Y. F., Huh, K. H., et al. (2010). Hippocampal NMDA receptor subunits differentially regulate fear memory formation and neuronal signal propagation. Hippocampus 20, 1072-1082. doi: 10.1002/hipo.20705

George, S. A., Hutson, P. H., and Stephens, D. N. (2009). Differential effects of MPEP and diazepam in tests of conditioned emotional response and Pavlovianto-instrumental transfer suggests "anxiolytic" effects are mediated by different mechanisms. Psychopharmacology (Berl.) 204, 499-509. doi: 10.1007/s00213009-1479-6

Harris, J. A., and Westbrook, R. F. (1998). Evidence that GABA transmission mediates context-specific extinction of learned fear. Psychopharmacology (Berl.) 140, 105-115. doi: 10.1007/s002130050745

Hasenöhrl, R. U., Topic, B., Frisch, C., Häcker, R., Mattern, C. M., and Huston, J. P. (1998). Dissociation between anxiolytic and hypomnestic effects for combined extracts of zingiber officinale and ginkgo biloba, as opposed to diazepam. Pharmacol. Biochem. Behav. 59, 527-535. doi: 10.1016/S0091-3057(97)00406-1 
Hoffman, J. R., Donato, A., and Robbins, S. J. (2004). Ginkgo biloba promotes short-term retention of spatial memory in rats. Pharmacol. Biochem. Behav. 77, 533-539. doi: 10.1016/j.pbb.2003.12.006

Impey, S., Obrietan, K., and Storm, D. R. (1999). Making new connections: role of ERK/MAP kinase signaling in neuronal plasticity. Neuron 23, 11-14. doi: 10.1016/S0896-6273(00)80747-3

Isoardi, N. A., Martijena, I. D., Carrer, H. F., and Molina, V. A. (2004). Increased fear learning coincides with neuronal dysinhibition and facilitated LTP in the basolateral amygdala following benzodiazepine withdrawal in rats. Neuropsychopharmacology 29, 1852-1864. doi: 10.1038/sj.npp. 1300478

Izquierdo, I. (1997). Memory formation: the sequence of biochemical events in the hippocampus and its connection to activity in other brain structures. Neurobiol. Learn. Mem. 68, 285-316. doi: 10.1006/nlme.1997.3799

Izquierdo, I., and Ferreira, M. B. (1989). Diazepam prevents post-training drug effects related to state dependency, but not post-training memory facilitation by epinephrine. Behav. Neural Biol. 51, 73-79. doi: 10.1016/S0163-1047(89) 90673-0

Izquierdo, I., and Medina, J. H. (1991). GABAA receptor modulation of memory: the role of endogenous benzodiazepines. Trends Pharmacol. Sci. 12, 260-265. doi: 10.1016/0165-6147(91)90567-C

Jacobs, B. L., and Azmitia, E. C. (1992). Structure and function of the brain serotonin system. Physiol. Rev. 72, 165-229.

Jensen, R. A., Martinez, J. L., Vasquez, B. J., and McGaugh, J. L. (1979). Benzodiazepines alter acquisition and retention of an inhibitory avoidance response in mice. Psychopharmacology (Berl.) 64, 125-126. doi: 10.1007/BF00427358

Ji, J., and Maren, S. (2007). Hippocampal involvement in contextual modulation of fear extinction. Hippocampus 17, 749-758. doi: 10.1002/hipo. 20331

Ji, J., and Maren, S. (2008). Differential roles for hippocampal areas CA1 and CA3 in the contextual encoding and retrieval of extinguished fear. Learn. Mem. 15, 244-251. doi: 10.1101/lm.794808

Joseph, J. A., Shukitt-Hale, B., and Casadesus, G. (2005). Reversing the deleterious effects of aging on neuronal communication and behavior: beneficial properties of fruit polyphenolic compounds. Am. J. Clin. Nutr. 81, 313S-316S.

Kalueff, A. V. (2007). Neurobiology of memory and anxiety: from genes to behavior. Neural Plast. 2007:78171. doi: 10.1155/2007/78171

Kehr, J., Yoshitake, S., Ijiri, S., Koch, E., Nöldner, M., and Yoshitake, T. (2012). Ginkgo biloba leaf extract (EGb $761^{\circledR}$ ) and its specific acylated flavonol constituents increase dopamine and acetylcholine levels in the rat medial prefrontal cortex: possible implications for the cognitive enhancing properties of EGb $761^{\circledR}$. Int. Psychogeriatr. 24(Suppl. 1), S25-S34. doi: $10.1017 / \mathrm{s} 1041610212000567$

Kim, J. H., and Richardson, R. (2010). Extinction in preweanling rats does not involve NMDA receptors. Neurobiol. Learn. Mem. 94, 176-182. doi: 10.1016/j.nlm.2010.05.004

Kim, J. J., and Fanselow, M. S. (1992). Modality-specific retrograde amnesia of fear. Science 256, 675-677. doi: 10.1126/science.1585183

Kimura, J., Nemoto, K., Degawa, M., Yokosuka, A., Mimaki, Y., Shimizu, K., et al. (2014). Upregulation of N-methyl-D-aspartate receptor subunits and c-Fos expressing genes in PC12D cells by nobiletin. Biol. Pharm. Bull. 37, 1555-1558. doi: 10.1248/bpb.b14-00177

Lengersdorf, D., Stüttgen, M. C., Uengoer, M., and Güntürkün, O. (2014). Transient inactivation of the pigeon hippocampus or the nidopallium caudolaterale during extinction learning impairs extinction retrieval in an appetitive conditioning paradigm. Behav. Brain Res. 265, 93-100. doi: 10.1016/j.bbr.2014.02.025

Leung, H. T., and Westbrook, R. F. (2008). Spontaneous recovery of extinguished fear responses deepens their extinction: a role for error-correction mechanisms. J. Exp. Psychol. Anim. Behav. Process. 34, 461-474. doi: 10.1037/00977403.34.4.461

Li, W., Trovero, F., Cordier, J., Wang, Y., Drieu, K., and Papadopoulos, V. (2003). Prenatal exposure of rats to Ginkgo biloba extract (EGb 761) increases neuronal survival/growth and alters gene expression in the developing fetal hippocampus. Brain Res. Dev. Brain Res. 144, 169-180. doi: 10.1016/S01653806(03)00168-8
Lin, C.-H., Yeh, S.-H., Lu, H.-Y., and Gean, P.-W. (2003). The similarities and diversities of signal pathways leading to consolidation of conditioning and consolidation of extinction of fear memory. J. Neurosci. 23, 8310-8317.

Lissek, S., and Güntürkün, O. (2003). Dissociation of extinction and behavioral disinhibition: the role of NMDA receptors in the pigeon associative forebrain during extinction. J. Neurosci. 23, 8119-8124.

Liu, X. B., Murray, K. D., and Jones, E. G. (2004). Switching of NMDA receptor $2 \mathrm{~A}$ and $2 \mathrm{~B}$ subunits at thalamic and cortical synapses during early postnatal development. J. Neurosci. 24, 8885-8895. doi: 10.1523/JNEUROSCI.247604.2004

Lovera, J. F., Kim, E., Heriza, E., Fitzpatrick, M., Hunziker, J., Turner, A. P., et al. (2012). Ginkgo biloba does not improve cognitive function in MS A randomized placebo-controlled trial. Neurology 79, 1278-1284. doi: 10.1212/WNL.0b013e31826aac60

Maher, P., Akaishi, T., and Abe, K. (2006). Flavonoid fisetin promotes ERKdependent long-term potentiation and enhances memory. Proc. Natl. Acad. Sci. U.S.A. 103, 16568-16573. doi: 10.1073/pnas.0607822103

Makkar, S. R., Zhang, S. Q., and Cranney, J. (2010). Behavioral and neural analysis of GABA in the acquisition, consolidation, reconsolidation, and extinction of fear memory. Neuropsychopharmacology 35, 1625-1652. doi: 10.1038/npp.2010.53

Malkani, S., and Rosen, J. B. (2000). Induction of NGFI-B mRNA following contextual fear conditioning and its blockade by diazepam. Brain Res. Mol. Brain Res. 80, 153-165. doi: 10.1016/S0169-328X(00)00130-3

Mansuri, M. L., Parihar, P., Solanki, I., and Parihar, M. S. (2014). Flavonoids in modulation of cell survival signalling pathways. Genes Nutr. 9:400. doi: 10.1007/ s12263-014-0400-z

Mathur, P., Graybeal, C., Feyder, M., Davis, M. I., and Holmes, A. (2009). Fear memory impairing effects of systemic treatment with the NMDA NR2B subunit antagonist, Ro 25-6981, in mice: attenuation with ageing. Pharmacol. Biochem. Behav. 91, 453-460. doi: 10.1016/j.pbb.2008.08.028

McNaughton, N., and Corr, P. J. (2004). A two-dimensional neuropsychology of defense: fear/anxiety and defensive distance. Neurosci. Biobehav. Rev. 28, 285-305. doi: 10.1016/j.neubiorev.2004.03.005

McNaughton, N., and Gray, J. A. (2000). Anxiolytic action on the behavioural inhibition system implies multiple types of arousal contribute to anxiety. J. Affect. Disord. 61, 161-176. doi: 10.1016/S0165-0327(00)00344-X

Meneses, A., and Perez-Garcia, G. (2007). 5-HT1A receptors and memory. Neurosci. Biobehav. Rev. 31, 705-727. doi: 10.1016/j.neubiorev.2007.02.001

Milad, M. R., Wright, C. I., Orr, S. P., Pitman, R. K., Quirk, G. J., and Rauch, S. L. (2007). Recall of fear extinction in humans activates the ventromedial prefrontal cortex and hippocampus in concert. Biol. Psychiatry 62, 446-454. doi: 10.1016/j.biopsych.2006.10.011

Millenson, J. R., and Leslie, J. (1974). The conditioned emotional response (CER) as a baseline for the study of anti-anxiety drugs. Neuropharmacology 13, 1-9. doi: 10.1016/0028-3908(74)90002-1

Mirza, N. R., Bright, J. L., Stanhope, K. J., Wyatt, A., and Harrington, N. R. (2005). Lamotrigine has an anxiolytic-like profile in the rat conditioned emotional response test of anxiety: a potential role for sodium channels? Psychopharmacology (Berl.) 180, 159-168. doi: 10.1007/s00213-005-2146-1

Miyamoto, J., Tsuji, M., Takeda, H., Nawa, H., and Matsumiya, T. (2000). Pretreatment with diazepam suppresses the reduction in defensive freezing behavior induced by fluvoxamine in the conditioned fear stress paradigm in mice. Eur. J. Pharmacol. 409, 81-84. doi: 10.1016/S0014-2999(00) 00722-6

Morris, R. G., Anderson, E., Lynch, G. S., and Baudry, M. (1986). Selective impairment of learning and blockade of long-term potentiation by an Nmethyl-D-aspartate receptor antagonist, AP5. Nature 319, 774-776. doi: 10.1038/319774a0

Morris, R. G. M. (2013). NMDA receptors and memory encoding. Neuropharmacology 74, 32-40. doi: 10.1016/j.neuropharm.2013.04.014

Munn, R. G. K., and McNaughton, N. (2008). Effects of fluoxetine on hippocampal rhythmic slow activity and behavioural inhibition. Behav. Pharmacol. 19, 257-264. doi: 10.1097/FBP.0b013e3282ff1300

Myers, K. M., and Davis, M. (2002). Behavioral and neural analysis of extinction. Neuron 36, 567-584. doi: 10.1016/S0896-6273(02)01064-4

Myung, J. K., Dunah, A. W., Yu, T. W., and Sheng, M. (2005). Differential roles of NR2A- and NR2B-containing NMDA receptors in Ras-ERK 
signaling and AMPA receptor trafficking. Neuron 46, 745-760. doi: 10.1016/j.neuron.2005.04.031

Nakajima, A., Yamakuni, T., Matsuzaki, K., Nakata, N., Onozuka, H., Yokosuka, A., et al. (2007). Nobiletin, a citrus flavonoid, reverses learning impairment associated with $\mathrm{N}$-methyl-D-aspartate receptor antagonism by activation of extracellular signal-regulated kinase signaling. J. Pharmacol. Exp. Ther. 321, 784-790. doi: 10.1124/jpet.106.117010

Oliveira, D. R., Sanada, P. F., Filhoa, C. S., Conceição, G. M. S., Cerutti, J. M., and Cerutti, S. M. (2013). Long-term treatment with standardized extract of Ginkgo biloba L. enhances the conditioned suppression of licking in rats by the modulation of neuronal and glial cell function in the dorsal hippocampus and central amygdala. Neuroscience 235, 70-86. doi: 10.1016/j.neuroscience.2013.01.009

Oliveira, D. R., Sanada, P. F., Saragossa Filho, A. C., Innocenti, L. R., Oler, G., Cerutti, J. M., et al. (2009). Neuromodulatory property of standardized extract Ginkgo biloba L. (EGb 761) on memory: behavioral and molecular evidence. Brain Res. 1269, 68-89. doi: 10.1016/j.brainres.2008.11.105

Przegalinski, E., Tatarczynska, E., and Chojnacka-Wójcik, E. (1995). The role of hippocampal 5-hydroxytryptamine 1A (5-HT1A) receptors in the anticonflict activity of beta-adrenoceptor antagonists. Neuropharmacology 34, 1211-1217. doi: 10.1016/0028-3908(95)00087-M

Quirk, G. J., and Mueller, D. (2008). Neural mechanisms of extinction learning and retrieval. Neuropsychopharmacology 33, 56-72. doi: 10.1038/sj.npp.1301555

Rendeiro, C., Foley, A., Lau, V. C., Ring, R., Rodriguez-Mateos, A., Vauzour, D., et al. (2014). A role for hippocampal PSA-NCAM and NMDA-NR2B receptor function in flavonoid-induced spatial memory improvements in young rats. Neuropharmacology 79, 335-344. doi: 10.1016/j.neuropharm.2013. 12.003

Rendeiro, C., Vauzour, D., Kean, R. J., Butler, L. T., Rattray, M., Spencer, J. P. E., et al. (2012). Blueberry supplementation induces spatial memory improvements and region-specific regulation of hippocampal BDNF mRNA expression in young rats. Psychopharmacology (Berl.) 223, 319-330. doi: 10.1007/s00213-012-2719-8

Rendeiro, C., Vauzour, D., Rattray, M., Waffo-Téguo, P., Mérillon, J. M., Butler, L. T., et al. (2013). Dietary levels of pure flavonoids improve spatial memory performance and increase hippocampal brain-derived neurotrophic factor. PLoS ONE 8:e63535. doi: 10.1371/journal.pone.0063535

Rescorla, R. A. (2004). Spontaneous recovery. Learn. Mem. 11, 501-509. doi: 10.1101/lm.77504

Risbrough, V. B., Brodkin, J. D., and Geyer, M. A. (2003). GABA-A and 5HT1A receptor agonists block expression of fear-potentiated startle in mice. Neuropsychopharmacology 28, 654-663. doi: 10.1038/sj.npp.1300079

Rudolph, U., and Möhler, H. (2006). GABA-based therapeutic approaches: GABAA receptor subtype functions. Curr. Opin. Pharmacol. 6, 18-23. doi: 10.1016/j.coph.2005.10.003

Rudolph, U., and Möhler, H. (2014). GABAA receptor subtypes: therapeutic potential in down syndrome, affective disorders, schizophrenia, and autism. Annu. Rev. Pharmacol. Toxicol. 54, 483-507. doi: 10.1146/annurev-pharmtox011613-135947

Sanders, M. J., Wiltgen, B. J., and Fanselow, M. S. (2003). The place of the hippocampus in fear conditioning. Eur. J. Pharmacol. 463, 217-223. doi: 10.1016/S0014-2999(03)01283-4

Santini, E., Muller, R. U., and Quirk, G. J. (2001). Consolidation of extinction learning involves transfer from NMDA-independent to NMDA-dependent memory. J. Neurosci. 21, 9009-9017.

Schenberg, E. E., Ferreira, T. L., Figueredo, L. Z., Hipólide, D. C., Nobrega, J. N., and Oliveira, M. G. (2006). Fear conditioning performance and NMDA receptor subtypes: NR2A differential expression in the striatum. Brain Res. Bull. 69, 440-446. doi: 10.1016/j.brainresbull.2006.02.010

Schroeter, H., Boyd, C., Spencer, J. P. E., Williams, R. J., Cadenas, E., and Rice-Evans, C. (2002). MAPK signaling in neurodegeneration: influences of flavonoids and of nitric oxide. Neurobiol. Aging 23, 861-880. doi: 10.1016/S0197-4580(02)00075-1

Shipton, O. A., and Paulsen, O. (2014). GluN2A and GluN2B subunit-containing NMDA receptors in hippocampal plasticity. Philos. Trans. R. Soc. Lond. B Biol. Sci. 369, 20130163. doi: 10.1098/rstb.2013.0163

Sotres-Bayon, F., Bush, D. E. A., and LeDoux, J. E. (2007). Acquisition of fear extinction requires activation of NR2B-containing NMDA receptors in the lateral amygdala. Neuropsychopharmacology 32, 1929-1940. doi: 10.1038/sj.npp.1301316

Sotres-Bayon, F., Diaz-Mataix, L., Bush, D. E., and LeDoux, J. E. (2009). Dissociable roles for the ventromedial prefrontal cortex and amygdala in fear extinction: NR2B contribution. Cereb. Cortex 19, 474-482. doi: 10.1093/cercor/ bhn099

Sotty, F., Sandner, G., and Gosselin, O. (1996). Latent inhibition in conditioned emotional response: c-fos immunolabelling evidence for brain areas involved in the rat. Brain Res. 737, 243-254. doi: 10.1016/0006-8993(96) 00737-8

Spencer, J. P. (2008). Flavonoids: modulators of brain function? Br. J. Nutr. 99 (E Suppl.), ES60-ES77. doi: 10.1017/S0007114508965776

Spencer, J. P. E. (2007). The interactions of flavonoids within neuronal signalling pathways. Genes Nutr. 2, 257-273. doi: 10.1007/s12263-007-0056-Z

Stanhope, K. J., and Dourish, C. T. (1996). Effects of 5-HT1A receptor agonists, partial agonists and a silent antagonist on the performance of the conditioned emotional response test in the rat. Psychopharmacology (Berl.) 128, 293-303. doi: $10.1007 / \mathrm{s} 002130050137$

Traynelis, S. F., Wollmuth, L. P., McBain, C. J., Menniti, F. S., Vance, K. M., Ogden, K. K., et al. (2010). Glutamate receptor ion channels: structure, regulation, and function. Pharmacol. Rev. 62, 405-496. doi: 10.1124/pr.109.002451

Vauzour, D. (2014). Effect of flavonoids on learning, memory and neurocognitive performance: relevance and potential implications for Alzheimer's disease pathophysiology. J. Sci. Food Agric. 94, 1042-1056. doi: 10.1002/jsfa.6473

Vauzour, D., Vafeiadou, K., Rodriguez-Mateos, A., Rendeiro, C., and Spencer, J. P. E. (2008). The neuroprotective potential of flavonoids: a multiplicity of effects. Genes Nutr. 3, 115-126. doi: 10.1007/s12263-008-0091-4

Vinogradova, O. S. (2001). Hippocampus as comparator: role of the two input and two output systems of the hippocampus in selection and registration of information. Hippocampus 11, 578-598. doi: 10.1002/hipo.1073

Wang, D., Cui, Z., Zeng, Q., Kuang, H., Wang, L. P., Tsien, J. Z., et al. (2009). Genetic enhancement of memory and long-term potentiation but not CA1 long-term depression in NR2B transgenic rats. PLoS ONE 4:e7486. doi: 10.1371/journal.pone.0007486

Wang, F., Shing, M., Huen, Y., Tsang, S. Y., and Xue, H. (2005). Neuroactive flavonoids interacting with GABAA receptor complex. Curr. Drug Targets CNS Neurol. Disord. 4, 575-585. doi: 10.2174/156800705774322030

Wang, F., Xu, Z., Ren, L., Tsang, S. Y., and Xue, H. (2008). GABAA receptor subtype selectivity underlying selective anxiolytic effect of baicalin. Neuropharmacology 55, 1231-1237. doi: 10.1016/j.neuropharm.2008.07.040

Wang, I. K., Lin-Shiau, S. Y., and Lin, J. K. (1999). Induction of apoptosis by apigenin and related flavonoids through cytochrome $\mathrm{c}$ release and activation of caspase- 9 and caspase-3 in leukaemia HL-60 cells. Eur. J. Cancer 35, 1517-1525. doi: 10.1016/S0959-8049(99)00168-9

Wang, Y., Wang, L., Wu, J., and Cai, J. (2006). The in vivo synaptic plasticity mechanism of EGb 761-induced enhancement of spatial learning and memory in aged rats. Br. J. Pharmacol. 148, 147-153. doi: 10.1038/sj.bjp.0706720

Williams, C. M., El Mohsen, M. A., Vauzour, D., Rendeiro, C., Butler, L. T., Ellis, J. A., et al. (2008). Blueberry-induced changes in spatial working memory correlate with changes in hippocampal CREB phosphorylation and brain-derived neurotrophic factor (BDNF) levels. Free Radic. Biol. Med. 45, 295-305. doi: 10.1016/j.freeradbiomed.2008. 04.008

Yee, B. K., Hauser, J., Dolgov, V. V., Keist, R., Möhler, H., Rudolph, U., et al. (2004). GABAA receptors containing the $\alpha 5$ subunit mediate the trace effect in aversive and appetitive conditioning and extinction of conditioned fear. Eur. J. Neurosci. 20, 1928-1936. doi: 10.1111/j.1460-9568.2004. 103642.X

Yeh, K.-Y., Shou, S.-S., Lin, Y.-X., Chen, C.-C., Chiang, C.-Y., and Yeh, C.Y. (2015). Effect of Ginkgo biloba extract on lipopolysaccharide-induced anhedonic depressive-like behavior in male rats. Phytother. Res. 29, 260-266. doi: $10.1002 /$ ptr.5247

Youdim, K. A., Shukitt-Hale, B., and Joseph, J. A. (2004). Flavonoids and the brain: interactions at the blood-brain barrier and their physiological effects on the central nervous system. Free Radic. Biol. Med. 37, 1683-1693. doi: 10.1016/j.freeradbiomed.2004.08.002

Yuen, E. Y., Jiang, Q., Chen, P., Gu, Z., Feng, J., and Yan, Z. (2005). Serotonin 5-HT1A receptors regulate NMDA receptor channels through 
a microtubule-dependent mechanism. J. Neurosci. 25, 5488-5501. doi: 10.1523/JNEUROSCI.1187-05.2005

Zhang, L.-M., Yao, J.-Z., Li, Y., Li, K., Chen, H.-X., Zhang, Y.-Z., et al. (2012). Anxiolytic effects of flavonoids in animal models of posttraumatic stress disorder. Evid. Based. Complement. Alternat. Med. 2012:623753. doi: $10.1155 / 2012 / 623753$

Zhang, X. H., Wu, L. J., Gong, B., Ren, M., Li, B. M., and Zhuo, M. (2008). Induction- and conditioning-protocol dependent involvement of NR2Bcontaining NMDA receptors in synaptic potentiation and contextual fear memory in the hippocampal CA1 region of rats. Mol. Brain 1:9. doi: $10.1186 / 1756-6606-1-9$
Conflict of Interest Statement: The authors declare that the research was conducted in the absence of any commercial or financial relationships that could be construed as a potential conflict of interest.

Copyright (๑) 2016 de Oliveira, Zamberlam, Rêgo, Cavalheiro, Cerutti and Cerutti. This is an open-access article distributed under the terms of the Creative Commons Attribution License (CC BY). The use, distribution or reproduction in other forums is permitted, provided the original author(s) or licensor are credited and that the original publication in this journal is cited, in accordance with accepted academic practice. No use, distribution or reproduction is permitted which does not comply with these terms. 